\title{
Modelling the sensitivity of soil mercury storage to climate-induced changes in soil carbon pools
}

\author{
O. Hararuk ${ }^{1}$, D. Obrist ${ }^{2}$, and Y. Luo ${ }^{1}$ \\ ${ }^{1}$ University of Oklahoma, Norman, Oklahoma, USA \\ ${ }^{2}$ Desert Research Institute, Reno, Nevada, USA \\ Correspondence to: O. Hararuk (ohararuk@ou.edu) \\ Received: 18 May 2012 - Published in Biogeosciences Discuss.: 23 August 2012 \\ Revised: 14 March 2013 - Accepted: 14 March 2013 - Published: 10 April 2013
}

\begin{abstract}
Substantial amounts of mercury $(\mathrm{Hg})$ in the terrestrial environment reside in soils and are associated with soil organic carbon $(\mathrm{C})$ pools, where they accumulated due to increased atmospheric deposition resulting from anthropogenic activities. The purpose of this study was to examine potential sensitivity of surface soil $\mathrm{Hg}$ pools to global change variables, particularly affected by predicted changes in soil $\mathrm{C}$ pools, in the contiguous US. To investigate, we included a soil $\mathrm{Hg}$ component in the Community Land Model based on empirical statistical relationships between soil $\mathrm{Hg} / \mathrm{C}$ ratios and precipitation, latitude, and clay; and subsequently explored the sensitivity of soil $\mathrm{C}$ and soil $\mathrm{Hg}$ densities (i.e., areal-mass) to climate scenarios in which we altered annual precipitation, carbon dioxide $\left(\mathrm{CO}_{2}\right)$ concentrations and temperature.

Our model simulations showed that current sequestration of $\mathrm{Hg}$ in the contiguous US accounted for 15230 metric tons of $\mathrm{Hg}$ in the top $0-40 \mathrm{~cm}$ of soils, or for over 300000 metric tons when extrapolated globally. In the simulations, US soil $\mathrm{Hg}$ pools were most sensitive to changes in precipitation because of strong effects on soil $\mathrm{C}$ pools, plus a direct effect of precipitation on soil $\mathrm{Hg} / \mathrm{C}$ ratios. Soil $\mathrm{Hg}$ pools were predicted to increase beyond present-day values following an increase in precipitation amounts and decrease following a reduction in precipitation. We found pronounced regional differences in sensitivity of soil $\mathrm{Hg}$ to precipitation, which were particularly high along high-precipitation areas along the West and East Coasts. Modelled increases in $\mathrm{CO}_{2}$ concentrations to $700 \mathrm{ppm}$ stimulated soil $\mathrm{C}$ and $\mathrm{Hg}$ accrual, while increased air temperatures had small negative effects on soil $\mathrm{C}$ and $\mathrm{Hg}$ densities. The combined effects of increased $\mathrm{CO}_{2}$, increased temperature and increased or de-
\end{abstract}

creased precipitation were strongly governed by precipitation and $\mathrm{CO}_{2}$ showing pronounced regional patterns. Based on these results, we conclude that the combination of precipitation and $\mathrm{CO}_{2}$ should be emphasised when assessing how climate-induced changes in soil $\mathrm{C}$ may affect sequestration of $\mathrm{Hg}$ in soils.

\section{Introduction}

Mercury $(\mathrm{Hg})$ is considered a global environmental pollutant and its dominant form in the atmosphere - gaseous elemental $\mathrm{Hg}$ - has a long atmospheric residence time (6 to 24 months), allowing for global redistribution (Schroeder and Munthe, 1998; Fitzgerald et al., 1998; Coughenour and Chen, 1997). Many natural sources emit $\mathrm{Hg}$ into the atmosphere - including volcanic sources, biomass burning and surface evasion - but during the last 150 years, atmospheric $\mathrm{Hg}$ loads are estimated to have increased three-to-five orders of magnitude due to anthropogenic emissions from gold mining, coal burning, waste incineration and industrial processes (Biester et al., 2003; Fitzgerald et al., 1998; Schuster et al., 2002; Streets et al., 2011). Mercury is of greatest concern when inorganic $\mathrm{Hg}$ is methylated and biomagnified through the food chain in aquatic and terrestrial ecosystems (Morel et al., 1998; Gnamuš et al., 2000), posing high exposure to top predators and humans.

$\mathrm{Hg}$ loads in remote terrestrial ecosystems are dominated by atmospheric deposition (Fitzgerald et al., 1998), and large pools of past Hg pollution - or "legacy" pollution - reside in surface litter and soil horizons (Grigal, 2003; Obrist et al., 2009). The accumulation of $\mathrm{Hg}$ in terrestrial ecosystems 
is many orders of magnitude larger than atmospheric pools (Obrist, 2007). Fate processes and potential changes in terrestrial $\mathrm{Hg}$ storage have important implications for global cycling of $\mathrm{Hg}$, including implications for back-evasion of $\mathrm{Hg}$ to the atmosphere or runoff to aquatic systems (Obrist, 2007; Smith-Downey et al., 2010). For example, bi-directional flux behaviour that $\mathrm{Hg}$ shows between terrestrial components and the atmosphere (Ericksen et al., 2006; Fritsche et al., 2008) is of concern for atmospheric Hg loads...(Ericksen et al., 2005; Harris et al., 2007; Pokharel and Obrist, 2011; Obrist et al., 2010b). Re-emissions of $\mathrm{Hg}$ from terrestrial surfaces - also termed secondary emissions - have the potential to become increasingly important due to a cumulative effect of past and ongoing pollution loads accumulating in surface reservoirs.

In terrestrial ecosystems, $\mathrm{Hg}$ mainly is bound to organic matter and carbon (C). In general, $\mathrm{Hg}$ depth distributions in soils follow those of soil organic matter, with the highest concentrations found in near-surface layers and decreasing concentrations with depth (Aastrup et al., 1991; Andersson, 1979; Meili, 1991; Obrist et al., 2009). Studies also show corresponding spatial distribution patterns of organic matter and $\mathrm{Hg}$ in top soils and litter across multiple sites (Grigal, 2003; Skyllberg et al., 2000; Obrist et al., 2009; Obrist et al., 2011). For example, Lag and Steinnes (Lag and Steinnes, 1978) reported positive correlations between organic matter and $\mathrm{Hg}$ (with $r^{2}$ of 0.58 and 0.55 , respectively) content across Eastern and Northern Norway humus layers, and Obrist et al. (2011) showed regressions between soil organic $C$ and $\mathrm{Hg}$ content with coefficient of determination, $r^{2}$, up to $47 \%$ across 14 US forest sites.

Given these correlations between organic matter and $\mathrm{Hg}$, we hypothesised that climate-induced changes in terrestrial $\mathrm{C}$ pools might have direct implications for $\mathrm{Hg}$ sequestered therein (Obrist, 2007). It is well known that soil C is highly sensitive to climate change - including changes in temperature, precipitation and carbon dioxide $\left(\mathrm{CO}_{2}\right)$ concentrations (Zheng et al., 2009; Reich and Schlesinger, 1992; Jobbagy and Jackson, 2000; Treseder et al., 2003; Natali et al., 2008). Atmospheric $\mathrm{CO}_{2}$ concentrations have been steadily increasing since 1850 and are now about $100 \mathrm{ppm}$ higher than preindustrial levels (Wigley, 1983), with recent increases among the strongest observed in historic times (e.g., $0.9{\mathrm{GtC} \mathrm{yr}^{-1}}^{-1}$ from 2000 to 2005 compared to $0.8 \mathrm{Gt} \mathrm{C} \mathrm{yr}^{-1}$ from 1990 to 1999; IPCC, 2007). Increases in $\mathrm{CO}_{2}$ concentrations are estimated to raise mean global surface temperatures between $1.8^{\circ} \mathrm{C}$ to $4^{\circ} \mathrm{C}$ by 2100 , depending on emission scenarios (IPCC, 2007). Responses of terrestrial $\mathrm{C}$ to climate change are complex: first, elevated atmospheric $\mathrm{CO}_{2}$ concentrations cause " $\mathrm{CO}_{2}$ fertilisation," stimulating live and dead biomass accrual and sequestering excess C (Luo et al., 2004; Oren et al., 2001; Norby and Iversen, 2006; Ainsworth and Long, 2005); second, warming experiments show that increasing soil temperatures stimulate soil heterotrophic respiration, thereby releasing sequestered $\mathrm{C}$ back into the atmosphere and decreasing soil $\mathrm{C}$ residence time (Oechel et al., 2000;
Rustad et al., 2001; Melillo et al., 2002); third, such C release upon warming only may occur under moist conditions while under dry conditions, soil respiration seems insensitive to temperature increases (Luo et al., 2001a). The sensitivity of soil $\mathrm{C}$ to altered precipitation is also variable; some studies show increases in soil $\mathrm{C}$ accumulation with increasing precipitation...(Jobbagy and Jackson, 2000; Zhou et al., 2002; Wang et al., 2005; Callesen et al., 2003; Saiz et al., 2012), but there is evidence that soil $\mathrm{C}$ may not change significantly (Zhou et al., 2009). A meta-analysis of the results from global change experiments (Wu et al., 2011) indicates that, overall, increased precipitation increases net $\mathrm{C}$ uptake by up to $56 \%$, while decreased precipitation decreases net $\mathrm{C}$ balance by up to $45 \%$. Ultimately, such changes in net C balance will translate into changes in soil $\mathrm{C}$ as soil $\mathrm{C}$ pools are formed by the long-term difference between $\mathrm{C}$ input and $\mathrm{C}$ release from soils.

The goal of our study was to perform sensitivity analyses to assess how potential changes in soil $\mathrm{C}$ induced by climate change may affect $\mathrm{Hg}$ sequestered in soils. We built on a spatial investigation of soil $\mathrm{Hg}$ and $\mathrm{C}$ across 14 US forest ecosystems that showed strong correlations between accumulation of soil $\mathrm{Hg}$ and soil $\mathrm{C}$ at a continental scale (Obrist et al., 2011; Obrist et al., 2012). We used a commonly employed global C model (Community Land Model CASA version 3.5; CLM-CASA) (Oleson, 2004; Randerson et al., 1997) to simulate soil $\mathrm{C}$ densities (in $\mathrm{g} \mathrm{m}^{-2}$ ) in the contiguous US. We simulated soil $\mathrm{Hg}$ by including $\mathrm{Hg} / \mathrm{C}$ ratios (obtained from the empirical relationships of $\mathrm{Hg} / \mathrm{C}$ ratios with precipitation, latitude and clay content) to the carbon cycle model and explored the potential sensitivity of soil $\mathrm{Hg}$ to changes in soil $\mathrm{C}$ and climate variables.

An important notion is that model predictions for soil $\mathrm{Hg}$ are based on observed, present-day statistical relationships between soil $\mathrm{Hg}$ and soil $\mathrm{C}$, precipitation, latitude and soil texture, found across 14 field sites. Specifically, our approach was not intended to simulate the complex biogeochemical processes that affect terrestrial $\mathrm{Hg}$ storage - including regional and local atmospheric deposition, retention capacity of $\mathrm{Hg}$, redox reactions, export from soils and many others. Statistical correlations of $\mathrm{Hg}$ to variables used in this study were assumed to stay constant under future conditions. While this may not be correct, our results allow exploration of which climate variables are most sensitive to affecting soil $\mathrm{Hg}$ sequestration through underlying soil $\mathrm{C}$ changes and direct effects of changed environmental conditions. In addition, our model allows evaluation of regional patterns where strongest sensitivity of both soil $\mathrm{C}$ and $\mathrm{Hg}$ are expected to occur. 


\section{Methods}

\subsection{Model implementation to predict present-day and future soil $\mathrm{C}$ and $\mathrm{Hg}$ densities}

Our modelling simulations are based on the Community Land Model, version 3.5 (CLM3.5) (Oleson, 2004; Oleson et al., 2008), which is predominantly used in the Community Earth System Model (CESM) and Community Atmosphere Model (CAM). This model allows assessment of the physical, chemical and biological processes by which terrestrial ecosystems are affected across a variety of spatial and temporal scales - including solar and long-wave radiation interactions with vegetation canopy and soil, soil and snow hydrology, heat transfer and other biogeophysical processes. For simulation of biogeochemical processes (i.e., soil $\mathrm{C}$ densities), we used the CASA (Carnegie-Ames-Stanford Approach) sub-model, modified for use in global climate models (Randerson et al., 1997). Each model grid cell was divided into five primary land cover types (glacier, lake, wetland, urban, vegetation), and vegetation land cover type was represented by 15 plant functional types - each of which was represented as a fraction of a grid cell inferred from $1 \mathrm{~km}$ satellite data (Bonan et al., 2002b; Bonan et al., 2002a). CLM-CASA' simulates gross primary productivity (GPP) and converts it to net primary productivity (NPP), assuming that plants use $50 \%$ of the newly acquired $\mathrm{C}$ for autotrophic respiration. NPP is then partitioned into three live $\mathrm{C}$ pools (stems, leaves, and roots) by three coefficients that vary with plant functional type and water availability. In forests, a fraction of NPP is allocated to stems; whereas in grasslands, NPP is partitioned between roots and leaves. If the plant functional type is water-limited at the particular time step, more $\mathrm{C}$ is allocated to roots. From the live pools, $\mathrm{C}$ transfers to the dead pools: first to litter and eventually to soil pools, respiring $\mathrm{CO}_{2}$ at each step of the transfer (Eq. 1):

$\frac{d \mathbf{X}(t)}{d t}=-\xi_{1}(t) \mathbf{A C X}(t)+\xi_{2}(t) \mathbf{B} U(t)$

where $\frac{d \mathbf{X}(t)}{d t}$ is change in each $\mathrm{C}$ pool at each time step, $\xi_{1}(t)$ is the function of the influence of climate on $C$ loss from each pool; $\mathbf{A}$ is a $12 \times 12$-sized matrix of partitioning coefficients between $\mathrm{C}$ pools, which includes soil texture and lignin influence on soil decomposition; $\mathbf{C}$ is the diagonal matrix of baseline $\mathrm{C}$ transfer coefficients, or the $\mathrm{C}$ loss rate at $25^{\circ} \mathrm{C}$; $\mathbf{X}(t)$ is a $12 \times 1$-sized vector of $\mathrm{C}$ pools (three live pools and nine dead pools); $\xi_{2}(t)$ is the function of water limitation of NPP partitioning between three live pools; $\boldsymbol{B}$ is the vector of the partitioning coefficients of NPP to the three live pools; and $U(t)$ is NPP.

We first used the CLM-CASA model to simulate soil C distribution in terrestrial ecosystems in the contiguous US. We then added an $\mathrm{Hg}$ component (Eq. 2) to the biogeochemistry module of the CLM-CASA model to predict soil $\mathrm{Hg}$ densities. Mercury was implemented into the model using

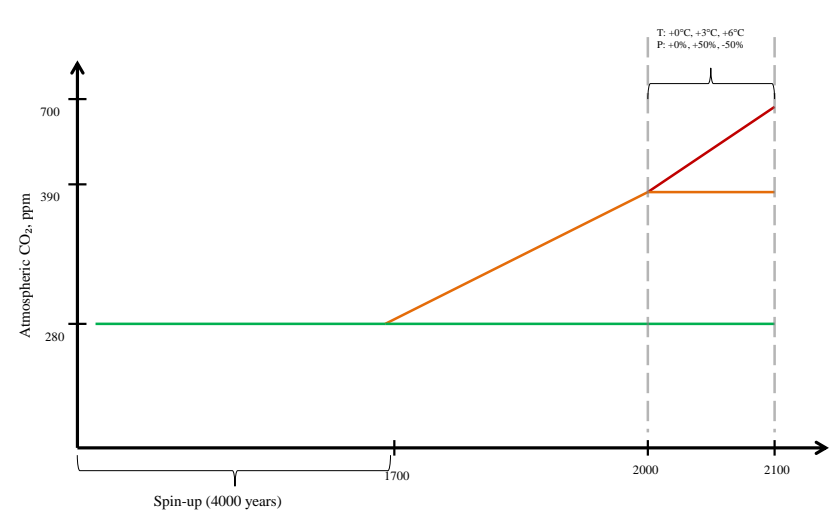

Fig. 1. Structure of the model run.

statistical relationships between $\mathrm{Hg} / \mathrm{C}$ ratios and latitude, precipitation, and soil texture observed in a field investigation of 14 forest sites across the US (Obrist et al., 2011). Hg levels were calculated based on the following linear multiregression model:

$\ln \left(\frac{\mathrm{Hg}}{\mathrm{C}}\right)=0.066 \cdot \mathrm{Lat}+0.001 \cdot P+0.05 \cdot$ Clay +3.059041

$\mathrm{Hg}=\frac{\left(\mathrm{C} \cdot \frac{\mathrm{Hg}}{\mathrm{C}}\right)}{1000000}$

where $\frac{\mathrm{Hg}}{\mathrm{C}}$ is an $\mathrm{Hg} / \mathrm{C}$ ratio $\left(\mu \mathrm{g} \mathrm{g}^{-1}\right)$, Lat is latitude (degrees), $P$ is annual precipitation (mm), Clay is clay content in the soil (\%), $\mathrm{Hg}$ is $\mathrm{Hg}$ density in the top $40 \mathrm{~cm}$ of soil $\left(\mu \mathrm{g} \mathrm{m}^{-2}\right.$ ), and $C$ is organic $\mathrm{C}$ density in the top $40 \mathrm{~cm}$ of soil $\left(\mathrm{g} \mathrm{m}^{-2}\right)$. This linear multi-regression model for $\mathrm{Hg} / \mathrm{C}$ ratios showed a coefficient of determination, $r^{2}$, of $50 \%$. In Obrist et al. (2011), we found that a multi-regression model with $\mathrm{Hg}$ concentration (as opposed to $\mathrm{Hg} / \mathrm{C}$ ratios) would increase $r^{2}$ from 0.50 to 0.87 ; but we chose to use $\mathrm{Hg} / \mathrm{C}$ ratios in our model because terrestrial $\mathrm{C}$ models generally predict soil $\mathrm{C}$ densities (in $\mathrm{g} \mathrm{m}^{-2}$ ) rather than $\mathrm{C}$ concentrations and conversion of $\mathrm{C}$ densities to $\mathrm{C}$ concentrations would require soil bulk densities which are not spatially available for the CLMCASA model.

To examine the effects of changing temperature, precipitation, and atmospheric $\mathrm{CO}_{2}$, we first ran (or spunup) the model until equilibrium state was reached (i.e., when annual net ecosystem $C$ exchange was close to zero; Fig. 1). The model was spun up for 4000 years according to the method described in the Carbon-Land Model Intercomparison Project (C-LAMP) by (Randerson et al., 2009). The model was cycled through atmospheric forcing data (three-hourly temperature, wind speed, precipitation, photosynthetically active radiation, humidity and surface pressure) (Qian, 2006) using climate data averaged for the period from 1948 to 1978 in the US. 


\subsubsection{Simulation scenarios to assess sensitivities of soil $\mathrm{C}$ and $\mathrm{Hg}$ densities to global change factors}

To simulate the sensitivity of soil $\mathrm{C}$ and $\mathrm{Hg}$ densities to various climate factors, we implemented three levels of treatments for each variable: 280,390 , and $700 \mathrm{ppm}$ for $\mathrm{CO}_{2} ;+0 \%,+50 \%$, and $-50 \%$ from present-day levels for precipitation; and $+0{ }^{\circ} \mathrm{C},+3{ }^{\circ} \mathrm{C}$, and $+6^{\circ} \mathrm{C}$ increase in mean annual temperature compared to present-day levels (Fig. 1). The $\mathrm{CO}_{2}$ and temperature changes were based on the changes projected by IPCC (IPCC, 2007). Ensemble model projections for the mean global precipitation range from $2.8 \%$ to $6.6 \%$ increase (Emori and Brown, 2005). However, precipitation change is highly variable on the regional scale; for instance, in Central USA precipitation amount is projected to decrease by up to $25 \%$ compared to the present-day levels, and in Northeast and Northwest of USA precipitation is anticipated to increase by about $10 \%$ (Emori and Brown, 2005). However, Zhang et al. (2007) showed that models do not represent regional variability well. For instance, models underpredicted historical 75 -year trend in precipitation by $300 \%$ along $30^{\circ} \mathrm{N}$ latitude, by $176 \%$ along $40^{\circ} \mathrm{N}$, and by $900 \%$ along $50^{\circ} \mathrm{N}$ (Zhang et al., 2007). Hence, we decided to change precipitation uniformly across USA by higher fractions than the ones predicted by (Emori and Brown, 2005).

To obtain the atmospheric $\mathrm{CO}_{2}$ level of $390 \mathrm{ppm}$, we gradually increased $\mathrm{CO}_{2}$ concentrations for 300 years to reach $390 \mathrm{ppm}$. We then kept it constant for the next 100 years of the model run. To obtain $\mathrm{CO}_{2}$ levels of $700 \mathrm{ppm}$, we gradually increased $\mathrm{CO}_{2}$ concentrations to $390 \mathrm{ppm}$ for 300 years. We then gradually increased the $\mathrm{CO}_{2}$ concentration for 100 years until it reached $700 \mathrm{ppm}$ by the end of 2100 . We increased the mean annual temperature and precipitation amount during these last 100 years of model runs for all runs.

\subsubsection{Calculating combined effects of changes in $\mathrm{CO}_{2}$, temperature, and precipitation}

We calculated six main effects representing impacts of individual climate change variables, 12 two-way interactive effects (data not shown, but used to calculated three-way effects), and eight three-way interactive effects combining changes in $\mathrm{CO}_{2}$ levels, temperature and precipitation. To calculate main and interactive effects, we used the method described earlier by (Luo et al., 2008). We calculated the main effect of an environmental factor by averaging nine simple effects of each environmental factor. For example, the effect of reduced precipitation under unchanged temperature and $\mathrm{CO}_{2}$ concentration was calculated as follows:

$P_{-50 \% 1}=\left(\mathrm{C}_{280} T_{+0} P_{-50 \%}-\mathrm{C}_{280} T_{+0} P_{+0} \%\right)$

where $\mathrm{C}_{280} T_{+0} P_{-50} \%$ represents the model run with unchanged temperature and $\mathrm{CO}_{2}$ concentrations, but with reduced precipitation. In similar ways, we calculated eight other simple effects of decreased precipitation using all com- binations of temperature and precipitation conditions, then averaged the effects for a main effect for reduced precipitation conditions. The same operation was repeated for the remaining five main effects.

Two-way interactive effects were calculated by averaging three simple effects of two variables altered simultaneously and subtracting the main effects of the corresponding variables. The simple effects were calculated as follows:

$$
\begin{aligned}
P_{-50 \%} \times T_{+31} & =\left(\mathrm{C}_{280} T_{+3} P_{-50 \%}-\mathrm{C}_{280} T_{+0} P_{+0} \%\right) \\
& \left.-P_{-50 \%}-T_{+3}\right)
\end{aligned}
$$

where $\mathrm{P}_{-50 \%} \times \mathrm{T}_{+31}$ is the simple effect of simultaneously reduced precipitation and increased temperature; $\mathrm{C}_{280} \mathrm{~T}_{+3} \mathrm{P}_{-50} \%$ is the model run with increased temperature (by $3{ }^{\circ} \mathrm{C}$ ), decreased precipitation and unchanged $\mathrm{CO}_{2}$; $\mathrm{C}_{280} \mathrm{~T}_{+0} \mathrm{P}_{+0} \%$ is the control run, $\mathrm{P}_{-50} \%$ is the main effect of reduced precipitation, and $\mathrm{T}_{+3}$ is the main effect of the $3{ }^{\circ} \mathrm{C}$ temperature increase. The same calculation was performed for two other simple effects for reduced precipitation and increased temperature. We then averaged the simple effects and subtracted from the average the main effects of reduced precipitation and increased temperature. We completed the same calculation for 11 other two-way interactive effects.

Three-way interactive effects were calculated by subtracting the main and two-way interactive effects from model runs with simultaneously altered $\mathrm{CO}_{2}$, temperature, and precipitation:

$$
\begin{aligned}
& P_{-50 \%} \times \mathrm{C}_{+110} \times T_{+3}=\left(\mathrm{C}_{+110} T_{+3} P_{-50 \%}-\mathrm{C}_{280} T_{+0} P_{+0} \%\right) \\
& -P_{-50 \%}-T_{+3}-\mathrm{C}_{+110}-P_{-50 \%} \times \mathrm{C}_{+110}-\mathrm{C}_{+110} \times T_{+3} \\
& -P_{-50 \%} \times T_{+3}
\end{aligned}
$$

where $P_{-50 \%} \times \mathrm{C}_{+110} \times T_{+3}$ is the magnitude of the threeway interactive effect between reduced precipitation, increased $\mathrm{CO}_{2}$, and increased temperature; $\mathrm{C}_{+110} T_{+3} P_{-50} \%$ is the model run in which we simultaneously decreased the precipitation amount while increasing $\mathrm{CO}_{2}$ and temperature; $P_{-50} \%, T_{+3}$, and $\mathrm{C}_{+110}$ are the main effects of decreased precipitation, temperature increased by $3{ }^{\circ} \mathrm{C}$, and $\mathrm{CO}_{2}$ increased by $110 \mathrm{ppm} ; P_{-50 \%} \times \mathrm{C}_{+110}, \mathrm{C}_{+110} \times T_{+3}$, and $P_{-50 \%} \times T_{+3}$ are two-way interactive effects of reduced precipitation and increased $\mathrm{CO}_{2}$, increased $\mathrm{CO}_{2}$ and increased temperature, and decreased precipitation and increased temperature.

To assess the strength of the two-way and three-way interactive effects, we calculated their strength relative to the averaged magnitude of the main corresponding effects. The relative strength for the two-way interactive effect was calculated as follows:

$I_{2}=\frac{2 \times T_{+3} \times P_{-50 \%} \%}{\left|P_{-50 \%}\right|+\left|T_{+3}\right|}$

where $I_{2}$ is a relative strength of the two-way interaction, $T_{+3} \times P_{-50 \%}$ is the magnitude of the two-way interactive effect of increased temperature and reduced precipitation, 
(A)
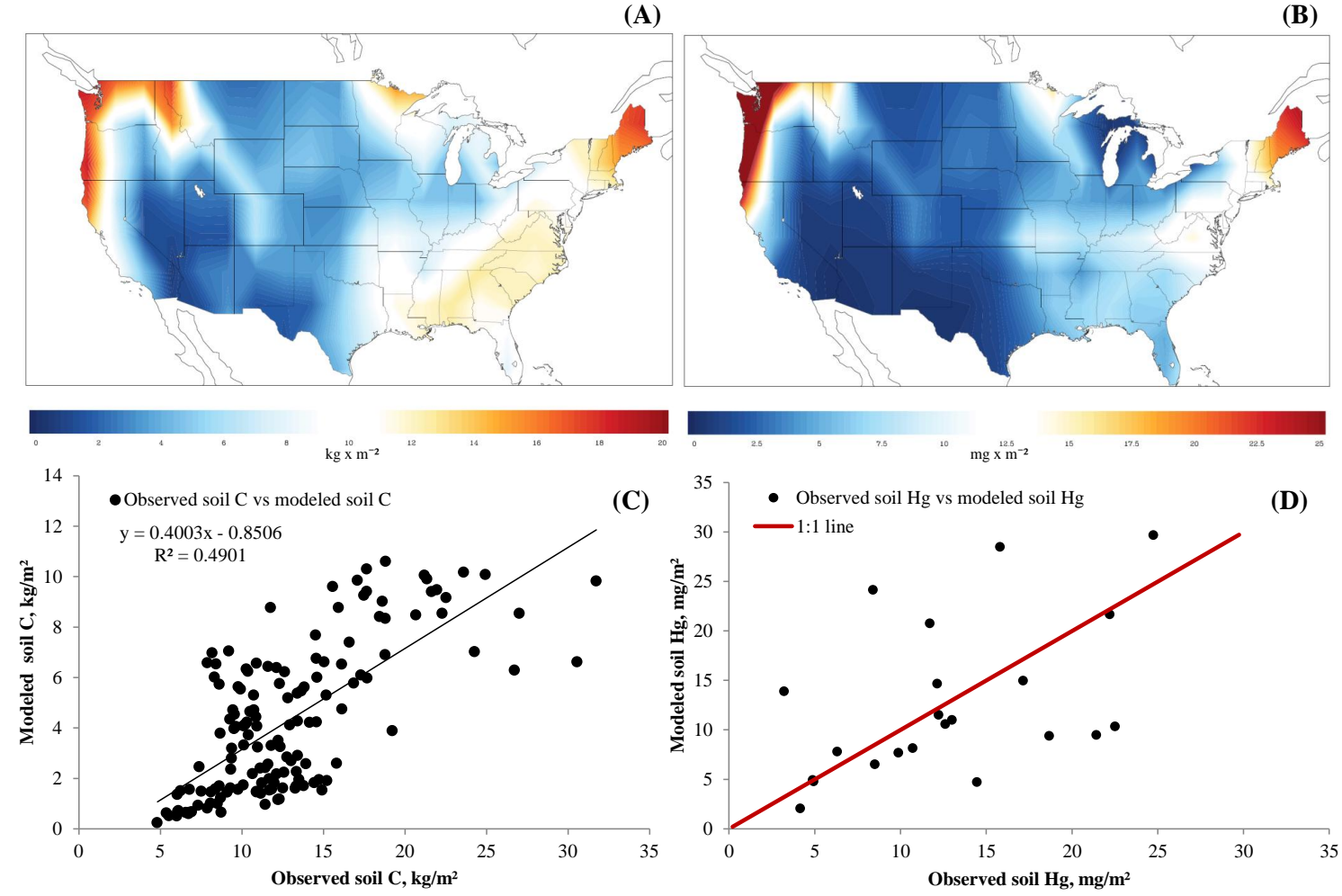

Fig. 2. Modelled present day carbon (A) and mercury (B) denities in the top $40 \mathrm{~cm}$ of soils of the contiguous United States. Comparisons of modelled and observed data of soil $\mathrm{C}$ and $\mathrm{Hg}$ densities $(\mathbf{C}$ and $\mathbf{D})$.

$P_{-50 \%}$ is the main effect of reduced precipitation and $T_{+3}$ is the main effect of increased temperature. The three-way interactive effect was calculated as follows:

$I_{2}=\frac{2 \times T_{+3} \times P_{-50 \%} \times \mathrm{C}_{+110}}{\left|P_{-50 \%}\right|+\left|T_{+3}\right|+\left|\mathrm{C}_{+110}\right|}$

where $T_{+3} \times P_{-50 \%} \times \mathrm{C}_{+110}$ is the magnitude of the threeway interactive effect between increased temperature, reduced temperature and increased $\mathrm{CO}_{2}$; and $\mathrm{C}_{+110}$ is the main effect of increased $\mathrm{CO}_{2}$.

The effects of the combined environmental variables for each run were calculated as the sum of all corresponding main and interactive effects.

\section{Results and discussion}

\subsection{Model evaluation and comparisons to observations and other model data}

Figure $2 \mathrm{a}$ and $\mathrm{b}$ show present-day soil $\mathrm{C}$ and $\mathrm{Hg}$ densities for the top $40 \mathrm{~cm}$ of soils as predicted by the model for the contiguous US Top soil $\mathrm{C}$ under present-day $\mathrm{CO}_{2}$ concentrations, temperature and precipitation ranged from 0.78 to $29.34 \mathrm{~kg} \mathrm{~m}^{-2}$. Spatial heterogeneity of soil C is mainly controlled by NPP, soil residence time, and human disturbance (e.g., conversion of grasslands to croplands) (Zhou and Luo,
2008; Guo et al., 2006). Both NPP and soil C residence time depend on temperature and precipitation. Apart from climate, soil residence times depend on soil texture and lignin content (Parton et al., 1987). If soil C is rich in lignin, the decomposition rate of soil $\mathrm{C}$ will be slower, increasing its residence time; soils higher in clay content tend to stabilise more $\mathrm{C}$, increasing soil $\mathrm{C}$ residence time. Previous study of soil C distribution in the conterminous US revealed that apart from land use change, precipitation has the most evident positive effect on soil $\mathrm{C}$; and, within narrow precipitation ranges, temperature controls soil $\mathrm{C}$ stocks and soil $\mathrm{C}$ decreases nonlinearly with increase in temperature (Guo and Gifford, 2002). We were able to duplicate general patterns of topsoil $\mathrm{C}$ distribution (Fig. 2a) in agreement with observational (Group, 2000; Guo et al., 2006) and modelling studies (Randerson et al., 2009). For example, we predicted that (i) lowest soil C densities would occur in the arid West and Midwest, caused by a combination of unfavourable climatic conditions for plant productivity (i.e., aridity) and land use (extensive areas occupied by croplands); (ii) higher $\mathrm{C}$ stocks in the forested zones of the northwestern, northeastern and southeastern US caused by higher plant productivity and higher annual rainfall; and (iii) latitudinal increases in soil $\mathrm{C}$ along the East and West Coasts in accordance with predicted temperature effects. 
In Fig. 2c, we compare $\mathrm{C}$ densities obtained by our simulation with observed soil $\mathrm{C}$ densities. For observed $\mathrm{C}$, we used the IGBP-DIS gridded soil $\mathrm{C}$ dataset with $5 \times 5$ arc minute resolution (Group, 2000). We found a good regression coefficient, $r^{2}$, between these two datasets of 0.49, indicating that our model simulation agreed relatively well with the observed data in regards to spatial patterns predicted for soil $\mathrm{C}$ distribution in the US. We found, however, that our modelling predictions underestimated soil $\mathrm{C}$ densities compared to the data from IGBP-DIS by approximately $60 \%$, and corrected modelled data for this underprediction. Discrepancies between observed values and model predictions can be explained by potential underestimation of soil C residence times; for instance, the residence times for slow, passive, and whole soil C pools produced by the CLM-CASA model for the Duke Forest were 9, 88 and 10 years, respectively; whereas Luo et al. (Luo et al., 2001b) reported 31, 885 and 47 years for the same $C$ pools. The cause for such underprediction may lie in underestimation of the lignin effect on soil residence times by the model, as well as underprediction of the effect of soil texture on soil C residence times (Parton et al., 1987).

Figure $2 \mathrm{~b}$ shows predicted soil $\mathrm{Hg}$ densities for the continental US, and Fig. 2d shows predicted soil $\mathrm{Hg}$ densities and observed $\mathrm{Hg}$ densities at 14 field observation sites plus additional published data found in sites across the US (Stamenkovic et al., 2008; Ma et al., 1997; Obrist et al., 2011; Amirbahman et al., 2004; Cohen et al., 2009; Demers et al., 2007; Dicosti et al., 2006; Dreher and Follmer, 2004; Grigal, 2003; Engle et al., 2006; Nater and Grigal, 1992; Natali et al., 2008). On average, observed and predicted soil $\mathrm{Hg}$ densities were within $15.6 \%$ of each other $(r=0.47, P=0.024)$. Best agreement was generally observed in sites located in Florida, Washington, California, Nevada, North Carolina and Tennessee, while Hg stocks were under and overpredicted at sites in Maine, New Hampshire and the Great Lakes region. Clearly, inaccuracies in predicted soil $\mathrm{C}$ densities directly affect predicted $\mathrm{Hg}$ densities because soil $\mathrm{C}$ density forms the underlying variability for $\mathrm{Hg}$ density predictions that are based on $\mathrm{Hg} / \mathrm{C}$ values. Furthermore, the coefficient of determination of the multiple linear regression model for $\mathrm{Hg} / \mathrm{C}$ ratios used to estimate $\mathrm{Hg}$ distribution is 0.50 ; hence, significant variability in the distribution of soil $\mathrm{Hg}$ must be explained by factors that are not included in our model. Many factors, including biogeochemical processes, spatial/temporal aspects of field sampling, regional pollution effects and others can explain the discrepancies between field observations and the model.

Spatial distribution patterns of model predictions generally agreed with those of soil $\mathrm{Hg}$ densities observed across field sites (i.e., Fig. 2d). Distribution of soil $\mathrm{Hg}$ densities also agreed well with observed and interpolated distribution of $\mathrm{Hg}$ concentrations, as extrapolated in a previous manuscript (Obrist et al., 2011). In that study, top soil Hg concentrations were extrapolated to the contiguous US based on a multi-

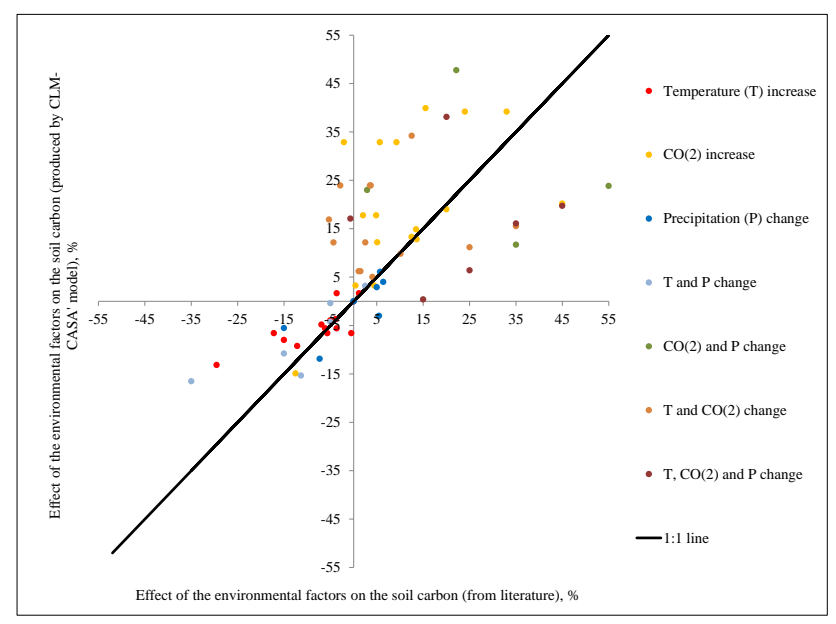

Fig. 3. Comparison of change in soil carbon in response to environmental factors reported in the literature to the change obtained in this study.

regression model with an $r^{2}$ of 0.88 ; these results showed a clear trend of increasing $\mathrm{Hg}$ concentrations with increasing latitude and highest $\mathrm{Hg}$ concentrations in the northeastern and northwestern US, in accordance with the predicted soil $\mathrm{Hg}$ density distributions in Fig. 2b: highest soil $\mathrm{Hg}$ densities were found in two sites located in Washington State and a site in Maine, while southwestern and midwestern pool sizes showed among the lowest soil $\mathrm{Hg}$ densities of all sites. Total soil $\mathrm{Hg}$ mass $(0-40 \mathrm{~cm}$ depth) estimated based on these model results accounted for 15230 metric tons of $\mathrm{Hg}$ across the US. When extrapolating these results further, we estimated a global $\mathrm{Hg}$ surface soil pool of over 300000 metric tons, which is almost two times the amount estimated by Corbitt et al. (2011)

In Figure 3, we compared sensitivity of soil C densities to variation in global change variables of our model simulations (as presented in Figs. 4 to 6) and those reported by Treseder et al. (2003), Natali et al. (2008); Pepper et al. (2005); Coughenour and Chen (1997); Cox et al. (2000); Cramer et al. (2001); Lichter et al. (2005); Lu et al. (2008); Shen et al. (2009); Talmon et al. (2011) and Wang et al. (2011). Specifically, we assessed the sensitivity of soil C densities to individual climate change variables, including increases in temperature, $\mathrm{CO}_{2}$, changes in precipitation patterns and combinations of these factors. We found, in general, good agreement in the direction of the soil $\mathrm{C}$ density changes: $91 \%$ of analysed data point pairs agreed in the direction of soil $\mathrm{C}$ density changes in the models; in only about $9 \%$ of predictions did we find that our model predicted different direction of soil $\mathrm{C}$ changes. For example, when comparing effects of $\mathrm{CO}_{2}$ on soil $\mathrm{C}$, we found relatively good correlation of predicted effects $(r=0.5, p=0.04)$. Most models, including ours, predicted soil $\mathrm{C}$ to increase significantly under elevated $\mathrm{CO}_{2}$, with the exception of the DayCent model (Pepper et 
al., 2005), which projected a decrease in soil $\mathrm{C}$ under elevated $\mathrm{CO}_{2}$ due to nitrogen limitation. Without the DayCent model data, the coefficient of determinations between ours and other simulations increased further $(r=0.6, p=0.018)$. Still, there are some discrepancies in regard to the magnitude of predicted soil $\mathrm{C}$ changes between our model and other model predictions; in particular, our simulations generally overpredicted effects of $\mathrm{CO}_{2}$ increases and temperature, plus $\mathrm{CO}_{2}$ increases on soil $\mathrm{C}$ content compared to other simulations. Our CLM-CASA model simulations on average overpredicted $\mathrm{CO}_{2}$ effects by $8.4 \%$ compared to other model simulations; without the DayCent model data, however, these differences in $\mathrm{CO}_{2}$ effects reduced to $5.7 \%$. In addition, our model underpredicted the combined effects of changes in temperature, $\mathrm{CO}_{2}$, and precipitation. Such differences may have been due to the use of different climate change scenarios: we compared model outputs from the simulation scenarios that differed from ours by $1{ }^{\circ} \mathrm{C}$ in temperature, up to $100 \mathrm{ppm}$ in $\mathrm{CO}_{2}$, and up to $20 \%$ in precipitation. Also, differences in model structures may have caused discrepancies in the predicted climate effect on soil $\mathrm{C}$, including parameterisations of water and nutrient limitations.

\subsection{Sensitivity of soil $\mathrm{C}$ and $\mathrm{Hg}$ densities to individual climate change variables}

\subsubsection{Sensitivity to change in air temperature}

Increases in air temperature (top panel) caused consistent decreases in soil $\mathrm{C}$ densities across all regions of the US; such responses to temperature have been well characterised and attributed to more significant stimulation of heterotrophic respiration with increasing temperature (Wu et al., 2011; Rustad et al., 2001; Zheng et al., 2009; Reich and Schlesinger, 1992) compared to temperature-induced stimulation of NPP (Rustad et al., 2001). The average C loss predicted by our model for a temperature increase of $6{ }^{\circ} \mathrm{C}$ is estimated at $10 \%$ and is similar to six models that predicted an average soil $\mathrm{C}$ decrease of $11 \%$ when temperature was increased by $5{ }^{\circ} \mathrm{C}$ (Cramer et al., 2001). Regional differences for soil $\mathrm{C}$ densities show that most pronounced losses are expected in the central and southeastern US (between 20 and $30 \%$ ). Observational studies by Guo et al (2006) reveal a polynomial relationship between soil $\mathrm{C}$ and temperature in high precipitation forests, such that soil $\mathrm{C}$ increases upon temperature change from $8^{\circ} \mathrm{C}$ to $11^{\circ} \mathrm{C}$, but not (or slightly decrease) upon temperature change from $8^{\circ} \mathrm{C}$ to $15^{\circ} \mathrm{C}$. Our spatial predictions agree with the above patterns: we observe very small decreases (and slight increases) in soil $\mathrm{C}$ densities in the northeast and northwest, while more southern sites showed pronounced losses of soil $\mathrm{C}$ densities. Guo et al. (2006) also indicated pronounced soil $\mathrm{C}$ losses (17 to $32 \%$ ) with temperature increases of $3{ }^{\circ} \mathrm{C}$ and $6{ }^{\circ} \mathrm{C}$ in a region with $1000-1150 \mathrm{~mm}$ precipitation ranges. Such precipitation corresponds, for example, to southeastern forests where our simulations predicted significant decreases in soil $\mathrm{C}$ as well. Guo et al. (2006) also report that drier grassland areas are more sensitive to temperature increase than forest areas with similar precipitation or forest areas with higher precipitation. In Fig. 4a, we observe that grasslands (e.g., in Texas, Kansas, Nebraska and South Dakota) tend to lose more C than forested areas (e.g., in Idaho, Washington, Maine) under temperature increases.

Based on the multi-linear model used for $\mathrm{Hg}$ soil density prediction, effects of temperature on soil $\mathrm{C}$ densities will directly and linearly feedback to soil $\mathrm{Hg}$ densities because $\mathrm{Hg} / \mathrm{C}$ ratios are directly multiplied by underlying soil $\mathrm{C}$ densities and because temperature has no direct statistical relationships with $\mathrm{Hg} / \mathrm{C}$ ratios (as opposed to precipitation, see below). Hence, our sensitivity analyses predicted identical changes in soil $\mathrm{Hg}$ compared to soil $\mathrm{C}$, with losses averaging $4.7 \%$ for a $3{ }^{\circ} \mathrm{C}$ increase in mean annual temperatures and $10 \%$ with a $6{ }^{\circ} \mathrm{C}$ increase across the continent. Responses of soil $\mathrm{Hg}$ densities are predicted to be highly regional and are expected to follow the spatial patterns discussed above in regards to soil $\mathrm{C}$ densities: the strongest responses on soil $\mathrm{Hg}$ densities are expected in the south and central US where our model predicts losses in soil $\mathrm{Hg}$ densities up to $30 \%$ of present-day levels. Further losses would be expected in the southern US and Great Plains while low sensitivity to air temperature is expected in the northeastern and northwestern US where soil C densities are not particularly sensitive to changes in temperature.

Our statistical modelling approach does not allow for characterisation of underlying processes that lead to changes in soil $\mathrm{Hg}$ densities, but it seems reasonable to assume that areas showing pronounced changes in soil $\mathrm{C}$ are those that might be most sensitive to changes in $\mathrm{Hg}$ that are generally sequestered in such $\mathrm{C}$ pools. Hence, it is likely that soil $\mathrm{Hg}$ pools most sensitive to temperature changes are those located in the central and southern US, while northwest and northeast areas show little sensitivity. We must, however, put strong limitations on the magnitude of predicted changes in soil $\mathrm{Hg}$ densities because using direct (i.e., linear) relationships between soil $\mathrm{Hg}$ and $\mathrm{C}$ changes that result from our model implementation are highly unlikely in reality. For example, linear responses between $\mathrm{Hg}$ and $\mathrm{C}$ changes might be expected upon complete loss of both $\mathrm{Hg}$ and organic $\mathrm{C}$ pools (e.g., that may occur in surface organic horizons during wildfires) where significant $\mathrm{Hg}$ losses have in fact been observed (Artaxo et al., 2000; Brunke et al., 2001; Friedli et al., 2001; Sigler et al., 2003; Turetsky et al., 2006; Obrist et al., 2008). In contrast, however, the few experimental studies that correspondingly measured the fate of $\mathrm{Hg}$ upon $\mathrm{C}$ mineralisation indicate that only a small fraction of $\mathrm{Hg}$ may be subject to volatilisation losses upon evasion of $\mathrm{CO}_{2}$ (Fritsche et al., 2008; Obrist et al., 2010b), which would indicate a much smaller magnitude of soil $\mathrm{Hg}$ losses compared to that of $\mathrm{C}$. The biogeochemistry of terrestrial $\mathrm{Hg}$ is very complex, including various deposition and emission pathways (Graydon 

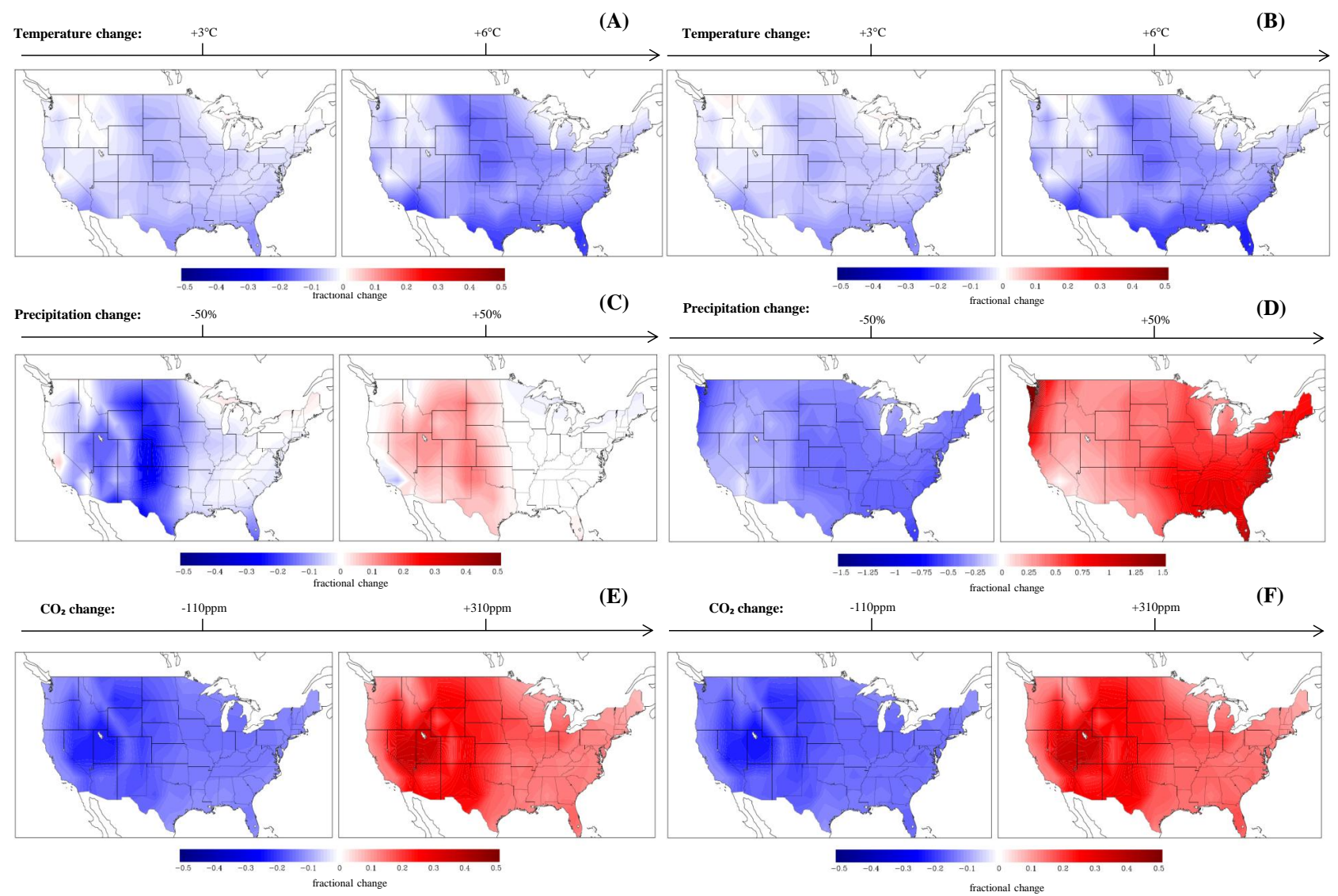

(B)

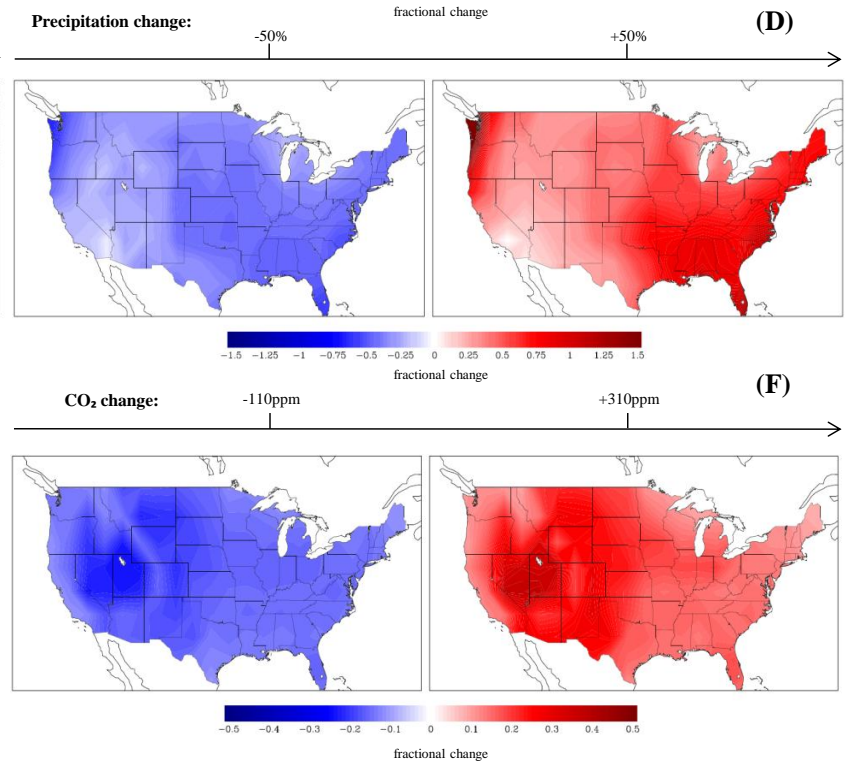

Fig. 4. Main effects of temperature, precipitation and $\mathrm{CO}_{2}$ on top soil carbon $(\mathbf{A}, \mathbf{C}, \mathbf{E})$ and top soil mercury densities $(\mathbf{B}, \mathbf{D}, \mathbf{F})$. The values are expressed as the fractional change of present-day pools.

et al., 2008b; Gustin et al., 2008), redox transformations between volatile and non-volatile $\mathrm{Hg}$ forms (Lalonde et al., 2001; Obrist et al., 2010a), and methylation and demethylation processes (Ullrich et al., 2001). The statistical approach used in this study does not allow simulating individual biogeochemical processes, and clearly the quantitative response of $\mathrm{Hg}$ upon changes in soil $\mathrm{C}$ will depend on these underlying processes and need to be addressed by further experimental studies.

\subsubsection{Sensitivity to precipitation changes}

Of the three variables tested, we found that changes in precipitation had the highest sensitivity for soil $\mathrm{Hg}$ densities (note different scales in Fig. 4). Unlike effects of temperature, our model predicted that precipitation affects soil $\mathrm{Hg}$ and soil $\mathrm{C}$ densities (Fig. 4c and d) in different ways. This is because changes in precipitation patterns affect underlying soil $\mathrm{C}$ densities and also $\mathrm{Hg} / \mathrm{C}$ ratios used to calculate soil $\mathrm{Hg}$ densities. For soil $\mathrm{C}$ densities, changes in precipitation patterns are highly regional; a $50 \%$ decrease in precipitation, for example, would decrease soil $\mathrm{C}$ densities - up to $33 \%$ - in the central part of the US and up to $18 \%$ in Florida; soil C densities, alternatively, remained relatively unchanged in many west coast regions with precipitation change; soil $\mathrm{C}$ densities even would decrease slightly in the northeast with increased precipitation. If we divided regions by precipitation gradients, we generally observed that with precipitation below $850 \mathrm{~mm}$ per year, a $50 \%$ decrease in precipitation would lead to strong decreases in soil C (34\% on average) and, hence, these decreases have greatest implications across the arid western and midwestern US.

We observed the same patterns under increased precipitation. For instance, more humic areas (such as coastal areas and southeastern US) showed less sensitivity to precipitation changes. Such patterns in soil $\mathrm{C}$ change are supported by Guo et al. (2006), who reported an increase in soil $\mathrm{C}$, on average by $23 \%$, with a $50 \%$ increase in precipitation if the original annual precipitation were up to $700 \mathrm{~mm}$. Altered precipitation influences both NPP and soil respiration (Wu et al., 2011; Huxman et al., 2004). Soil respiration generally is more sensitive to precipitation in dry areas compared to wet areas (Wu et al., 2011), thereby increasing sensitivity to respective changes in arid regions. NPP in areas with high rainfall also is less sensitive to additional precipitation compared to arid regions (Huxman et al., 2004). Hence, in mesic 
regions, additional precipitation will cause little to no change in NPP and little increase in soil respiration; in dry regions, additional precipitation particularly will stimulate NPP - but less so heterotrophic respiration - resulting in net gains in $\mathrm{C}$ accumulation (Wu et al., 2011). Drought conditions will cause a disproportionately large $\mathrm{C}$ imbalance in arid ecosystems - despite relatively uniform water use efficiency - compared to mesic regions due to strong sensitivity of soil respiration to reduced rainfall (Wu et al., 2011; Huxman et al., 2004).

The sensitivity of soil $\mathrm{Hg}$ densities to precipitation is spatially different compared to that of soil $\mathrm{C}$ densities, which is due to the additional effect that precipitation has on $\mathrm{Hg} / \mathrm{C}$ ratios. We previously observed that annual precipitation is positively correlated to soil $\mathrm{Hg}$ concentrations across US forests (Obrist et al., 2011), and the multi-regression equation above (Eq. 2) accounts for this influence also in regard to $\mathrm{Hg} / \mathrm{C}$ ratios. Hence, soil $\mathrm{Hg}$ densities are expected to decrease under reduced precipitation more than would be expected purely due to changes in soil $\mathrm{C}$, and increase more than soil $\mathrm{C}$ under increased precipitation scenarios. Assuming linearity between soil $\mathrm{C}$ and soil $\mathrm{Hg}$ changes, we found that effects of increased precipitation on $\mathrm{Hg} / \mathrm{C}$ ratios alone accounted for about $53 \%$ of the changes in soil $\mathrm{Hg}$ densities, which in reality is likely even higher. Our model sensitivity study indicated that sensitivity of soil $\mathrm{Hg}$ changes follows precipitation gradients across the US. For example, assuming linearity between soil $\mathrm{C}$ and $\mathrm{Hg}$ changes, a $50 \%$ decrease in annual precipitation would decrease $\mathrm{Hg}$ stocks by $10 \%$ of present day values in southern California and Arizona, but would be much stronger (up to $75 \%$ ) in the northwest as well as along the US east coast. Further, lower sensitivities to changes in precipitation are predicted to occur in the arid intermountain west, while sensitivities increase gradually towards the east coast and were particularly high in the eastern and southeastern US.

Aside from the direct effects of soil $\mathrm{C}$ on soil $\mathrm{Hg}$ densities discussed above, a variety of other processes could explain responses of $\mathrm{Hg}$ concentrations and $\mathrm{Hg} / \mathrm{C}$ ratios to changes in precipitation. For example, precipitation amounts may directly lead to changes in wet deposition loads (NADP, 2011) leading to changes in soil $\mathrm{Hg}$ densities (although such effects may be highly nonlinear due to "washout" effects (Lamborg et al., 1995; Landis et al., 2002; Lyman and Gustin, 2008; Mason et al., 1997; Faïn et al., 2011). Further, correlations between annual precipitation and soil Hg may be caused by canopy wash-off and throughfall deposition which in forest ecosystems is a significant deposition flux (Demers et al., 2007; Rea et al., 1996; Graydon et al., 2008a), and such deposition loads likely would be efficiently retained in ecosystems (e.g., soils generally retain more than $90 \%$ of $\mathrm{Hg}$ deposited with rainfall; Ericksen et al., 2005; Harris et al., 2007; Graydon et al., 2009; Hintelmann et al., 2002). Other reasons for effects of precipitation on soil $\mathrm{Hg}$ storage are different representations of biomes and soil types in different climate zones.

\subsection{Sensitivity to changes in $\mathrm{CO}_{2}$ concentrations}

Increased $\mathrm{CO}_{2}$ concentrations showed the second highest sensitivity on soil $\mathrm{Hg}$ densities. As with effects of temperature, changes in $\mathrm{CO}_{2}$ levels only affect soil $\mathrm{Hg}$ densities through changes in underlying soil $\mathrm{C}$ pools in our model; hence, spatial responses to $\mathrm{CO}_{2}$ concentration changes are equivalent for soil $\mathrm{Hg}$ and $\mathrm{C}$, and the patterns described below, hence, apply for both soil $\mathrm{C}$ and $\mathrm{Hg}$ densities. When we increased $\mathrm{CO}_{2}$ by $110 \mathrm{ppm}$ from $280 \mathrm{ppm}$, soil $\mathrm{C}$ and $\mathrm{Hg}$ densities increased by up to $22 \%$, with the most responsive areas located in water-limited western lands. When $\mathrm{CO}_{2}$ levels were increased by $420 \mathrm{ppm}$ from $280 \mathrm{ppm}$, soil C and $\mathrm{Hg}$ densities increased by up to $50 \%$. Many studies are available on effects of $\mathrm{CO}_{2}$ concentration on terrestrial $\mathrm{C}$; in general, studies show that increased $\mathrm{CO}_{2}$ leads to a fertilisation effect (Ainsworth and Long, 2005; Norby et al., 2005). Additional $\mathrm{CO}_{2}$ leads to increased water use efficiency (Eamus, 1991), plant productivity (De Graaff et al., 2006), plant light-use efficiency (Kubiske and Pregitzer, 1996), and generally also to increased tissue C / N ratios (De Graaff et al., 2006; Luo et al., 2006). Soil $\mathrm{C}$ tends to increase in grasslands $(10 \%)$ more than in forests (6\%), with a $\mathrm{CO}_{2}$ increase to $550 \mathrm{ppm}$ (Luo et al., 2006). These patterns of expected changes in soil $\mathrm{C}$ and $\mathrm{Hg}$ densities to $\mathrm{CO}_{2}$ increases are reflected in our predicted sensitivity maps: for example, the Great Plains show a higher sensitivity to changes in $\mathrm{CO}_{2}$ concentrations as compared to northwestern and northeastern forests; the arid intermountain west and the southwestern US shows strong sensitivities of soil C density; and smaller changes are expected to occur along coastal areas and in the southeastern US. Changes in soil $\mathrm{C}$ densities are mainly due to stimulation of NPP (i.e., $\mathrm{CO}_{2}$ fertilisation effect), as evident by predicted whole plant $\mathrm{C}$ increases for most biomes under increasing $\mathrm{CO}_{2}$; through time, however, progressive nitrogen limitation decreases the response of plant productivity to $\mathrm{CO}_{2}$ increases in nutrient poor areas (Oren et al., 2001; Luo et al., 2004; Norby and Iversen, 2006). Although some studies indicate an increase in soil respiration with elevated $\mathrm{CO}_{2}$, carbon dioxide has no stimulation effect on cumulative soil respiration during the long-term (Bader and Korner, 2010; Johnson et al., 2001; Tingey et al., 2006).

Two studies using Free-Air- $\mathrm{CO}_{2}$-Enrichment (FACE) experiments showed that a $\mathrm{CO}_{2}$ increase from $393 \mathrm{ppm}$ to $549 \mathrm{ppm}$ at the Oak Ridge FACE site increased soil Hg content by $33 \%$; an increase in $\mathrm{CO}_{2}$ from $382 \mathrm{ppm}$ to $582 \mathrm{ppm}$ at the Duke FACE site increased soil $\mathrm{Hg}$ content by $21 \%$ (Natali et al., 2008). These soil $\mathrm{Hg}$ increases were preliminarily attributed to corresponding increases in top soil organic $\mathrm{C}$ content, suggesting that changes in soil $\mathrm{C}$ may directly cause changes in soil $\mathrm{Hg}$. Effects of $\mathrm{CO}_{2}$ on $\mathrm{Hg}$ accumulation, however, may in fact not be limited to changes in underlying soil $\mathrm{C}$ densities; Millhollen et al. (2006) showed that plant exposure to elevated $\mathrm{CO}_{2}$ led to lower foliar $\mathrm{Hg}$ concentrations in plants; they also suggested that leaf $\mathrm{Hg}$ uptake is controlled 

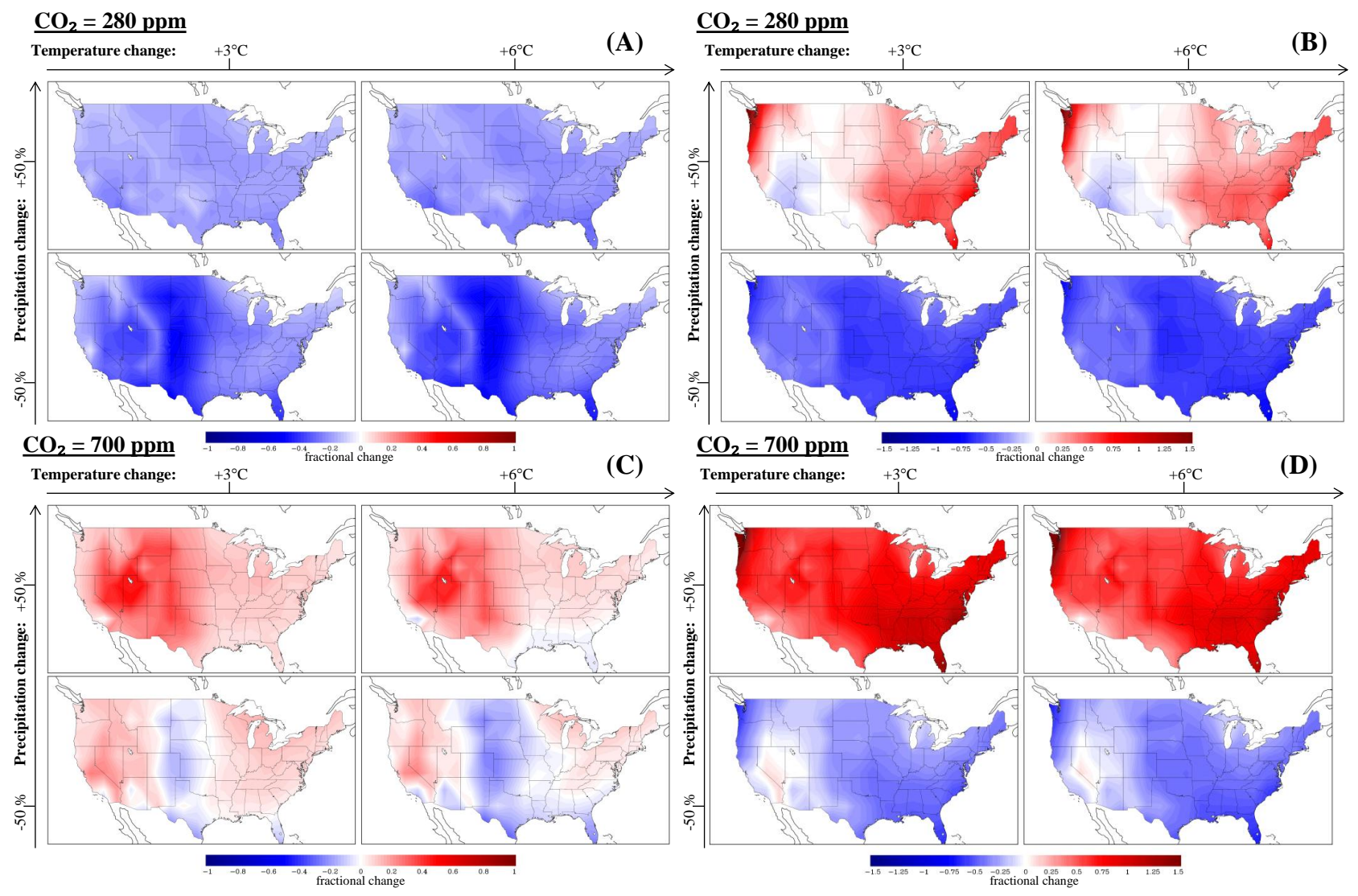

Fig. 5. Combined effects of changes in temperature, precipitation and $\mathrm{CO}_{2}$ on soil carbon (A, C) and soil mercury (B, D) densities. A and $\mathbf{B}$ represent the three way interactive effects with $\mathrm{CO}_{2}$ concentrations of pre-industrial levels ( -110 ppm of present-day), and $\mathbf{C}$ and $\mathbf{D}$ show effects with $\mathrm{CO}_{2}$ elevated by $420 \mathrm{ppm}$ from present-day levels. Values are expressed as the fractional change of present-day pools.

by leaf physiological processes, including stomatal conductance which is typically reduced under elevated $\mathrm{CO}_{2}$. Natali et al. (2008) also found slightly lower foliar $\mathrm{Hg}$ concentrations in elevated $\mathrm{CO}_{2}$ treatments, but the differences were not significant. Further studies are needed to assess additional effects that changes in $\mathrm{CO}_{2}$ concentrations may have on $\mathrm{Hg}$ cycling to accurately assess effects of global change.

\subsection{Combined effects of climate-change variables on soil $\mathrm{C}$ and $\mathrm{Hg}$ densities}

Climate change factors are not purely additive, but can show strong interactive effects between factors, which affects calculation of the combined effects of changes in temperature, precipitation and $\mathrm{CO}_{2}$ concentrations. Luo et al. (2008) found that the most significant interactive effects occurred between $\mathrm{CO}_{2}$ and precipitation, and we found similar model simulation results. For example, interactive effects between changes in precipitation and $\mathrm{CO}_{2}$ can be expected (as discussed in Sect. 3.2.3) because the response of change in $\mathrm{CO}_{2}$ is highly dependent on soil water availability across different US regions. Hence, the response of $\mathrm{CO}_{2}$ is highly dependent on soil water status, and any combination of changes in pre- cipitation and $\mathrm{CO}_{2}$ will show interactive effects on the predicted sensitivity of soil $\mathrm{C}$ and soil $\mathrm{Hg}$ densities. We found that other combinations of climate variables (such as temperature and precipitation) had relatively minor interactive effects; for these combinations, the response to climate variables is close to the additive effect of individual global climate variables.

Figure 5 shows the combined sensitivity of the three tested climate variables on soil $\mathrm{C}$ and soil $\mathrm{Hg}$ densities. In general, we found similar responses to changes in environmental variables as highlighted above. Since the strongest sensitivity for soil $\mathrm{C}$ and $\mathrm{Hg}$ densities was predicted to occur in response to changes in precipitation (Sect. 3.2.2), changes in precipitation also mainly drove the changes when all three variables were combined. These interactive effects also showed that soil $\mathrm{C}$ and $\mathrm{Hg}$ densities were least sensitive to temperature changes compared to $\mathrm{CO}_{2}$ and precipitation changes; hence, we found relatively small additional differences in precipitation changes compared to the greater effects of $\mathrm{CO}_{2}$. Figure 5 highlights the sensitivity of soil $\mathrm{C}$ and soil $\mathrm{Hg}$ densities, suggesting it may be most important to focus on effects of $\mathrm{CO}_{2}$ and precipitation and their combinations, as these show 
greatest sensitivity and strong interactive effects. This is in agreement with the results of both modelling studies and meta-analyses, focusing on the effects of precipitation and $\mathrm{CO}_{2}$ on the $\mathrm{C}$ cycle (Luo et al., 2008; Housman et al., 2006; De Graaff et al., 2006; Natali et al., 2008).

\section{Conclusions}

In conclusion, our study assessed potential sensitivity of changes in climate variables on soil $\mathrm{C}$ density distribution across the US, which we used to assess how this might affect soil $\mathrm{Hg}$ pools that show correlations to soil $\mathrm{C}$ distributions. It is important to note that our study was not intended to simulate process-driven and biogeochemical changes in $\mathrm{Hg}$ cycling under climate change, but rather was based on statistical relationships of $\mathrm{Hg}$ to soil $\mathrm{C}$ and other environmental variables observed in the field under present-day conditions.

Our study indicated a high sensitivity (on average $+16 \%$ of present-day levels) with a $\mathrm{CO}_{2}$ increase from $390 \mathrm{ppm}$ to $700 \mathrm{ppm}$ for soil $\mathrm{C}$ densities, which is likely to show strong potential for significant changes in soil $\mathrm{Hg}$ due to their association. This result is in agreement with field observations showing that soil $\mathrm{Hg}$ is sensitive to $\mathrm{CO}_{2}$-induced increases in soil $\mathrm{C}$ pools in two experimental forest $\mathrm{CO}_{2}$ manipulation studies (Natali et al., 2008). Unlike effects of $\mathrm{CO}_{2}$, changes in precipitation patterns were anticipated to show dissimilar spatial changes for soil $\mathrm{C}$ and soil $\mathrm{Hg}$, in particular, because precipitation was expected to affect both soil $\mathrm{C}$ and soil $\mathrm{Hg} / \mathrm{C}$ levels. Both soil C and soil $\mathrm{Hg}$ were only moderately sensitive to increases in temperature, and the resulting regional patterns were mainly determined by stimulation of NPP. Finally, the combined effects of the three climate variables indicated that overall response is highly driven by the combination of $\mathrm{CO}_{2}$ and precipitation. Under increasing $\mathrm{CO}_{2}$ and precipitation, we expect stimulation of soil $\mathrm{Hg}$ densities due to large-scale increases in soil $\mathrm{C}$ densities, plus direct effects of increased precipitation. Under decreasing precipitation and increasing $\mathrm{CO}_{2}$, however, our model predicted losses of soil $\mathrm{C}$ densities and associated losses in soil $\mathrm{Hg}$. Our simulations strongly indicated that the overall response of climate change on soil $\mathrm{C}$ and soil $\mathrm{Hg}$ densities is likely to be highly regional.

This study cannot pinpoint the fate or underlying processes that cause losses or increased accumulation of $\mathrm{Hg}$ in soils. On regional scales, however, scenarios that result in losses of $\mathrm{Hg}$ from soils might increase mobilisation of $\mathrm{Hg}$ and adversely affect watershed and ecosystem health in these respective regions; conversely, increased soil accumulation of $\mathrm{Hg}$ might increase immobilisation and sequestration of $\mathrm{Hg}$ thereby potentially reducing bioavailability and exposure. On a global scale, increased soil $\mathrm{Hg}$ storage might be beneficial in reducing time periods of surface-atmosphere cycling and re-emissions of $\mathrm{Hg}$, reduced atmospheric exposure and global re-distribution; conversely, if significant soil $\mathrm{Hg}$ are re-emitted due to global change or ecosystem disturbances, the legacy of past anthropogenic pollution sources will continue to cycle through environmental compartments. Given the enormous global storage pool of $\mathrm{Hg}$ in surface soils, further experimental studies that focus on fate of terrestrial $\mathrm{Hg}$ are needed.

Acknowledgements. We thank Roger Kreidberg for his help with manuscript editing. This study was funded by the US Environmental Protection Agency (US EPA) through a Science-ToAchieve-Results grant (No. R833378).

Edited by: E. Veldkamp

\section{References}

Aastrup, M., Johnson, J., Bringmark, E., Bringmark, I., and Iverfeldt, A.: Occurence and transport of mercury within a small catchment area, Water Air Soil Pollut., 56, 155-167, doi:10.1007/BF00342269, 1991.

Ainsworth, E. A. and Long, S. P.: What have we learned from 15 years of free-air $\mathrm{CO}_{2}$ enrichment (FACE)? A meta-analytic review of the responses of photosynthesis, canopy properties and plant production to rising $\mathrm{CO}_{2}$, New Phytol., 165, 351-372, doi:10.1111/j.1469-8137.2004.01224.x, 2005.

Amirbahman, A., Ruck, P. L., Fernandez, I. J., Haines, T. A., and Kahl, J. A.: The Effect of Fire on Mercury Cycling in the Soils of Forested Watersheds: Acadia National Park, Maine, U.S.A, Water Air Soil Pollut., 152, 315-331, doi:10.1023/B:WATE.0000015369.02804.15, 2004.

Andersson, A.: Mercury in soils, Elsevier, Amsterdam, 79-112, 1979.

Artaxo, P., Calixto de Campos, R., Fernandes, E. T., Martins, J. V., Xiao, Z., Lindqvist, O., Fernández-Jiménez, M. T., and Maenhaut, W.: Large scale mercury and trace element measurements in the Amazon basin, Atmos. Environ., 34, 4085-4096, doi:10.1016/S1352-2310(00)00106-0, 2000.

Bader, M. K. F. and Korner, C.: No overall stimulation of soil respiration under mature deciduous forest trees after 7 years of $\mathrm{CO}_{2}$ enrichment, Global Change Biol., 16, 2830-2843, doi:10.1111/j.1365-2486.2010.02159.x, 2010.

Biester, H., Martinez-Cortizas, A., Birkenstock, S., and Kilian, R.: Effect of Peat Decomposition and Mass Loss on Historic Mercury Records in Peat Bogs from Patagonia, Environ. Sci. Technol., 37, 32-39, doi:10.1021/es025657u, 2003.

Bonan, G. B., Oleson, K. W., Vertenstein, M., Levis, S., Zeng, X., Dai, Y., Dickinson, R. E., and Yang, Z.-L.: The Land Surface Climatology of the Community Land Model Coupled to the NCAR Community Climate Model, J. Climate, 3123-3149, doi:10.1175/1520-0442(2002)015<3123:TLSCOT>2.0.CO;2, $2002 \mathrm{a}$.

Bonan, G. B., Levis, S., Kergoat, L., and Oleson, K. W.: Landscapes as patches of plant functional types: An integrating concept for climate and ecosystem models, Global Biogeochem. Cycl., 16, 1021-1044, doi:10.1029/2000GB001360, 2002b.

Brunke, E., Labuschagne, C., and Slemr, F.: Gaseous mercury emissions from a fire in the Cape Peninsula, South Africa, 
during January 2000, Geophys. Res. Lett., 28, 1483-1486, doi:10.1029/2000GL012193, 2001.

Callesen, I., Liski, J., Raulund-Rasmussen, K., Olsson, M. T., Tau-Strand, L., Vesterdal, L., and Westman, C. J.: Soil carbon stores in Nordic well-drained forest soils - relationships with climate and texture class, Global Change Biol., 9, 358-370, doi:10.1046/j.1365-2486.2003.00587.x, 2003.

Cohen, M. J., Lamsal, S., Osborne, T. Z., Bonzongo, J. C. J., Newman, S., and Reddy, R. K.: Soil Total Mercury Concentrations across the Greater Everglades, Soil Sci. Soc. Am. J., 73, 675685, doi:10.2136/sssaj2008.0126, 2009.

Corbitt, E. S., Jacob, D. J., Holmes, C. D., Streets, D. G., and Sunderland, E. M.: Global Source-Receptor Relationships for Mercury Deposition Under Present-Day and 2050 Emissions Scenarios, Environ. Sci. Techn., 45, 10477-10484, doi:10.1021/es202496y, 2011.

Coughenour, M. B. and Chen, D. X.: Assessment of grassland ecosystem responses to atmospheric change using linked plant-soil process models, Ecol. Appl., 7, 802-827, doi:10.2307/2269435, 1997.

Cox, P. M., Betts, R. A., Jones, C. D., Spall, S. A., and Totterdell, A. J.: Acceleration of global warming due to carbon-cycle feedbacks in a coupled climate model, Nature, 408, 184-187, doi:10.1038/35041539, 2000.

Cramer, W., Bondeau, A., Woodward, F. I., Prentice, I. C., Betts, R. A., Brovkin, V., Cox, P. M., Fisher, V., Foley, J. A., Friend, A. D., Kucharik, C., Lomas, M. R., Ramankutty, N., Sitch, S., Smith, B., White, A., and Young-Molling, C.: Global response of terrestrial ecosystem structure and function to $\mathrm{CO}_{2}$ and climate change: results from six dynamic global vegetation models, Global Change Biol., 7, 357-373, doi:10.1046/j.13652486.2001.00383.x, 2001.

De Graaff, M. A., Van Groenigen, K. J., Six, J., Hungate, B., and Van Kessel, C.: Interactions between plant growth and soil nutrient cycling under elevated $\mathrm{CO}_{2}$ : a meta-analysis, Global Change Biol., 12, 2077-2091, doi:10.1111/j.1365-2486.2006.01240.x, 2006.

Demers, J. D., Driscoll, C. T., Fahey, T. J., and Yavitt, J. B.: Mercury cycling in litter and soil in different forest types in the Adirondack region, New York, USA, Ecol. Appl., 17, 13411351, doi:10.1890/06-1697.1, 2007.

Dicosti, R., Callaham, M., and Stanturf, J.: Atmospheric Deposition and Re-Emission of Mercury Estimated in a Prescribed ForestFire Experiment in Florida, USA, Water Air Soil Pollut., 176, 77-91, doi:10.1007/s11270-006-9149-3, 2006.

Dreher, G. B. and Follmer, L. R.: Mercury Content of Illinois Soils, Water Air Soil Pollut., 156, 299-315, doi:10.1023/b:wate.0000036824.07207.16, 2004.

Eamus, D.: The interaction of rising $\mathrm{CO}_{2}$ and temperatures with water use efficiency, Plant Cell Environ., 14, 843-852, doi:10.1111/j.1365-3040.1991.tb01447.x, 1991.

Emori, S. and Brown, S. J.: Dynamic and thermodynamic changes in mean and extreme precipitation under changed climate, Geophys. Res. Lett., 32, doi:10.1029/2005GL023272, 2005.

Engle, M. A., Gustin, M. S., Johnson, D. W., Murphy, J. F., Miller, W. W., Walker, R. F., Wright, J., and Markee, M.: Mercury distribution in two Sierran forest and one desert sagebrush steppe ecosystems and the effects of fire, Sci. Total Environ., 367, 222233, doi:10.1016/j.scitotenv.2005.11.025, 2006.
Ericksen , J. A., Gustin, M. S., Lindberg, S. E., Olund, S. E., and Krabbenhoft, D. P.: Assessing the Potential for Re-emission of Mercury Deposited in Precipitation from Arid Soils Using a Stable Isotope, Environ. Sci. Technol., 39, 8001-8007, doi:10.1021/es0505651, 2005.

Ericksen, J. A., Gustin, M. S., Xin, M., Weisberg, P. J., and Fernandez, G. C. J.: Air-soil exchange of mercury from background soils in the United States, Sci. Total Environ., 366, 851-863, doi:10.1016/j.scitotenv.2005.08.019, 2006.

Faïn, X., Obrist, D., Pierce, A., Barth, C., Gustin, M. S., and Boyle, D. P.: Whole-watershed mercury balance at Sagehen Creek, Sierra Nevada, CA, Geochim. Cosmochim. Ac., 75, 2379-2392, doi:10.1016/j.gca.2011.01.041, 2011.

Fitzgerald, W. F., Engstrom, D. R., Mason, R. P., and Nater, E. A.: The Case for Atmospheric Mercury Contamination in Remote Areas, Environ. Sci. Techn. 32, 1-7, doi:10.1021/es970284w, 1998.

Friedli, H. R., Radke, L. F., and Lu, J. Y.: Mercury in smoke from biomass fires, Geophys. Res. Lett., 28, 3223-3226, doi:10.1029/2000GL012704, 2001.

Fritsche, J., Obrist, D., Zeeman, M. J., Conen, F., Eugster, W., and Alewell, C.: Elemental mercury fluxes over a sub-alpine grassland determined with two micrometeorological methods, Atmos. Environ., 42, 2922-2933, doi:10.1016/j.atmosenv.2007.12.055, 2008.

Gnamuš, A., Byrne, A. R., and Horvat, M.: Mercury in the Soil-Plant-Deer-Predator Food Chain of a Temperate Forest in Slovenia, Environ. Sci. Technol., 34, 3337-3345, doi:10.1021/es991419w, 2000.

Graydon, J. A., St. Louis, V. L., Hintelmann, H., Lindberg, S. E., Sandilands, K. A., Rudd, J. W. M., Kelly, C. A., Hall, B. D., and Mowat, L. D.: Long-Term Wet and Dry Deposition of Total and Methyl Mercury in the Remote Boreal Ecoregion of Canada, Environ. Sci. Technol., 42, 8345-8351, doi:10.1021/es801056j, 2008a.

Graydon, J. A., St. Louis, V. L., Hintelmann, H., Lindberg, S. E., Sandilands, K. A., Rudd, J. W. M., Kelly, C. A., Hall, B. D., and Mowat, L. D.: Long-Term Wet and Dry Deposition of Total and Methyl Mercury in the Remote Boreal Ecoregion of Canada, Environ. Sci. Technol., 42, 8345-8351, 10.1021/es801056j, 2008b.

Graydon, J. A., St. Louis, V. L., Hintelmann, H., Lindberg, S. E., Sandilands, K. A., Rudd, J. W. M., Kelly, C. A., Tate, M. T., Krabbenhoft, D. P., and Lehnherr, I.: Investigation of Uptake and Retention of Atmospheric $\mathrm{Hg}$ (II) by Boreal Forest Plants Using Stable Hg Isotopes, Environ. Sci. Technol., 43, 4960-4966, doi:10.1021/es900357s, 2009.

Grigal, D. F.: Mercury Sequestration in Forests and Peatlands, J. Environ. Qual., 32, 393-405, doi:10.2134/jeq2003.3930, 2003.

Guo, L. B. and Gifford, R. M.: Soil carbon stocks and land use change: a meta analysis, Glob. Change Biol., 8, 345-360, doi:10.1046/j.1354-1013.2002.00486.x, 2002.

Guo, Y., Gong, P., Amundson, R., and Yu, Q.: Analysis of Factors Controlling Soil Carbon in the Conterminous United States, Soil Sci. Soc. Am. J., 70, 601-612, doi:10.2136/sssaj2005.0163, 2006.

Gustin, M. S., Lindberg, S. E., and Weisberg, P. J.: An update on the natural sources and sinks of atmospheric mercury, Appl. Geochem., 23, 482-493, doi:10.1016/j.apgeochem.2007.12.010, 2008. 
Harris, R. C., Rudd, J. W. M., Amyot, M., Babiarz, C. L., Beaty, K. G., Blanchfield, P. J., Bodaly, R. A., Branfireun, B. A., Gilmour, C. C., Graydon, J. A., Heyes, A., Hintelmann, H., Hurley, J. P., Kelly, C. A., Krabbenhoft, D. P., Lindberg, S. E., Mason, R. P., Paterson, M. J., Podemski, C. L., Robinson, A., Sandilands, K., Southworth, G. R., St. Louis, V. L., and Tate, M. T.: Whole-ecosystem study shows rapid fish-mercury response to changes in mercury deposition, P. Natl. A. Sci., 104, 1658616591, doi:10.1073/pnas.0704186104, 2007.

Hintelmann, H., Harris, R., Heyes, A., Hurley, J. P., Kelly, C. A., Krabbenhoft, D. P., Lindberg, S. E., Rudd, J. W. M., Scott, K. J., and St.Louis, V. L.: Reactivity and Mobility of New and Old Mercury Deposition in a Boreal Forest Ecosystem during the First Year of the METAALICUS Study, Environ. Sci. Technol., 36, 5034-5040, doi:10.1021/es025572t, 2002.

Housman, D., Naumburg, E., Huxman, T., Charlet, T., Nowak, R., and Smith, S.: Increases in Desert Shrub Productivity under Elevated Carbon Dioxide Vary with Water Availability, Ecosystems, 9, 374-385, doi:10.1007/s10021-005-0124-4, 2006.

Huxman, T. E., Smith, M. D., Fay, P. A., Knapp, A. K., Shaw, M. R., Loik, M. E., Smith, S. D., Tissue, D. T., Zak, J. C., Weltzin, J. F., Pockman, W. T., Sala, O. E., Haddad, B. M., Harte, J., Koch, J. W., Schwinning, S., Small, E. E., and Williams, D. G.: Convergence across biomes to a common rain-use efficiency, Nature, 429, 651-654, doi:10.1038/nature02561, 2004.

IPCC: Climate Change 2007: The Physical Science Basis. Contribution of Working Group I to the Fourth Assessment Report of the Intergovernmental Panel on Climate Change, edited by: Solomon, S., Qin, D., Manning, M., Chen, Z., Marquis, M., Averyt, K. B., Tignor, M., and Miller, H. L., Cambridge University Press, Cambridge, UK and New York, NY, USA, 996 pp., 2007.

Jobbagy, E. G. and Jackson, R. B.: The Vertical Distribution of Soil Organic Carbon and Its Relation to Climate and Vegetation, Ecol. Appl., 10, 423-436, doi:10.1890/10510761(2000)010[0423:TVDOSO]2.0.CO;2, 2000.

Johnson, D. W., Hungate, B. A., Dijkstra, B., Hymus, G., and Drake, B.: Effects of Elevated Carbon Dioxide on Soils in a Florida Scrub Oak Ecosystem, J. Environ. Qual., 30, 501-507, doi:10.2134/jeq2001.302501x, 2001.

Kubiske, M. E., and Pregitzer, K. S.: Effects of elevated $\mathrm{CO}_{2}$ and light availability on the photosynthetic light response of trees of contrasting shade tolerance, Tree Physiol., 16, 351-358, doi:10.1093/treephys/16.3.351, 1996.

Lag, J. and Steinnes, E.: Regional distribution of mercury in humus layers of Norwegian forest soils, Acta Agr. Scand., 28, 393-396, 1978.

Lalonde, J. D., Poulain, A. J., and Amyot, M.: The Role of Mercury Redox Reactions in Snow on Snow-to-Air Mercury Transfer, Environ. Sci. Technol., 36, 174-178, doi:10.1021/es010786g, 2001.

Lamborg, C. H., Fitzgerald, W. F., Vandal, G. M., and Rolfhus, K. R.: Atmospheric mercury in northern Wisconsin: Sources and species, Water Air Soil Pollut., 80, 189-198, doi:10.1007/BF01189667, 1995.

Landis, M. S., Vette, A. F., and Keeler, G. J.: Atmospheric Mercury in the Lake Michigan Basin: Influence of the Chicago/Gary Urban Area, Environ. Sci. Technol., 36, 45084517, doi:10.1021/es011216j, 2002.

Lichter, J., Barron, S. H., Bevacqua, C. E., Finzi, A. C., Irving, K. F., Stemmler, E. A., and Schlesinger, W. H.: Soil carbon seques- tration and turnover in a pine forest after six years of atmospheric $\mathrm{CO}_{2}$ enrichment, Ecology, 86, 1835-1847, doi:10.1890/04-1205, 2005.

Lu, X. Y., Cheng, G. W., Xiao, F. P., and Fan, J. H.: Modeling effects of temperature and precipitation on carbon characteristics and GHGs emissions in Abies fabric forest of subalpine, J. Environ. Sci., 20, 339-346, doi:10.1016/s1001-0742(08)60053-4, 2008.

Luo, Y., Wan, S., Hui, D., and Wallace, L. L.: Acclimatization of soil respiration to warming in a tall grass prairie, Nature, 413, 622-625, doi:10.1038/35098065, 2001a.

Luo, Y., Wu, L., Andrews, J., White, L., Matamala, R., Schäfer, K., and Schlesinger, W. H.: Elevated $\mathrm{CO}_{2}$ differentiates ecosystem carbon processes: deconvolution analysis of Duke forest FACE data, Ecological Monographs, 71, 357-376, doi:10.1890/00129615(2001)071[0357:ECDECP]2.0.CO;2, 2001b.

Luo, Y., Su, B. O., Currie, W. S., Dukes, J. S., Finzi, A., Hartwig, U., Hungate, B., Murtrie, R. E., Oren, R. A. M., Parton, W. J., Pataki, D. E., Shaw, R. M., Zak, D. R., and Field, C. B.: Progressive Nitrogen Limitation of Ecosystem Responses to Rising Atmospheric Carbon Dioxide, BioScience, 54, 731-739, doi:10.1641/00063568(2004)054[0731:PNLOER]2.0.CO;2, 2004.

Luo, Y., Hui, D., and Zhang, D.: Elevated $\mathrm{CO}_{2}$ stimulates net accumulations of carbon and nitrogen in land ecosystems: a metaanalysis, Ecology, 87, 53-63, doi:10.1890/04-1724, 2006.

Lyman, S. N., and Gustin, M. S.: Speciation of atmospheric mercury at two sites in northern Nevada, USA, Atmos. Environ., 42, 927939, doi:10.1016/j.atmosenv.2007.10.012, 2008.

Ma, L. Q., Tan, F., and Harris, W. G.: Concentrations and distributions of eleven metals in Florida soils, Journal of Environmental Quality, 26, 769-775, 10.2134/jeq1997.00472425002600030025x, 1997.

Mason, R. P., Lawson, N. M., and Sullivan, K. A.: The concentration, speciation and sources of mercury in Chesapeake Bay precipitation, Atmos. Environ., 31, 3541-3550, doi:10.1016/S13522310(97)00206-9, 1997.

Meili, M.: The coupling of mercury and organic matter in the biogeochemical cycle - towards a mechanistic model for the boreal forest zone, Water Air Soil Pollut., 56, 333-347, doi:10.1007/BF00342281, 1991.

Melillo, J. M., Steudler, P. A., Aber, J. D., Newkirk, K., Lux, H., Bowles, F. P., Catricala, C., Magill, A., Ahrens, T., and Morrisseau, S.: Soil Warming and Carbon-Cycle Feedbacks to the Climate System, Science, 298, 2173-2176, doi:10.1126/science.1074153, 2002.

Millhollen, A. G., Obrist, D., and Gustin, M. S.: Mercury accumulation in grass and forb species as a function of atmospheric carbon dioxide concentrations and mercury exposures in air and soil, Chemosphere, 65, 889-897, doi:10.1016/j.chemosphere.2006.03.008, 2006.

Morel, F. M. M., Kraepiel, A. M. M., and Amyot, M.: The chemical cycle and bioaccumulation of mercury, Ann. Rev. Ecol. Syst., 29, 543-566, doi:10.1146/annurev.ecolsys.29.1.543, 1998.

Mercury Deposition network: http://nadp.sws.uiuc.edu/lib/data/ 2010as.pdf, 2011.

Natali, S., Sañudo-Wilhelmy, S., Norby, R., Zhang, H., Finzi, A., and Lerdau, M.: Increased mercury in forest soils under elevated carbon dioxide, Oecologia, 158, 343-354, doi:10.1007/s00442008-1135-6, 2008. 
Nater, E. A. and Grigal, D. F.: Regional trends in mercury distribution across the Great Lakes states, north central USA, Nature, 358, 139-141, doi:10.1038/358139a0, 1992.

Norby, R. J., DeLucia, E. H., Gielen, B., Calfapietra, C., Giardina, C. P., King, J. S., Ledford, J., McCarthy, H. R., Moore, D. J. P., Ceulemans, R., De Angelis, P., Finzi, A. C., Karnosky, D. F., Kubiske, M. E., Lukac, M., Pregitzer, K. S., ScarasciaMugnozza, G. E., Schlesinger, W. H., and Oren, R.: Forest response to elevated $\mathrm{CO}_{2}$ is conserved across a broad range of productivity, P. Natl. A. Sci. USA, 102, 18052-18056, doi:10.1073/pnas.0509478102, 2005.

Norby, R. J. and Iversen, C. M.: Nitrogen uptake, distribution, turnover, and efficiency of use in a $\mathrm{CO}_{2}$-enriched Sweetgum forest, Ecology, 87, 5-14, doi:10.1890/04-1950, 2006.

Obrist, D.: Atmospheric mercury pollution due to losses of terrestrial carbon pools?, Biogeochemistry, 85, 119-123, doi:10.1007/s10533-007-9108-0, 2007.

Obrist, D., Moosmüller, H., Schürmann, R., Chen, A. L. W., and Kreidenweis, S. M.: Particulate-Phase and Gaseous Elemental Mercury Emissions During Biomass Combustion: Controlling Factors and Correlation with Particulate Matter Emissions, Environ. Sci. Technol., 42, 721-727, doi:10.1021/es071279n, 2008.

Obrist, D., Johnson, D. W., and Lindberg, S. E.: Mercury concentrations and pools in four Sierra Nevada forest sites, and relationships to organic carbon and nitrogen, Biogeosciences, 6, 765777, doi:10.5194/bg-6-765-2009, 2009.

Obrist, D., Faïn, X., and Berger, C.: Gaseous elemental mercury emissions and $\mathrm{CO}_{2}$ respiration rates in terrestrial soils under controlled aerobic and anaerobic laboratory conditions, Sci. Total Environ., 408, 1691-1700, doi:10.1016/j.scitotenv.2009.12.008, 2010a.

Obrist, D., Faïn, X., and Berger, C.: Gaseous elemental mercury emissions and $\mathrm{CO}_{2}$ respiration rates in terrestrial soils under controlled aerobic and anaerobic laboratory conditions, Sci. Total Environ., 408, 1691-1700, 10.1016/j.scitotenv.2009.12.008, $2010 b$

Obrist, D., Johnson, D. W., Lindberg, S. E., Luo, Y., Hararuk, O., Bracho, R., Battles, J. J., Dail, D. B., Edmonds, R. L., Monson, R. K., Ollinger, S. V., Pallardy, S. G., Pregitzer, K. S., and Todd, D. E.: Mercury Distribution Across 14 US Forests. Part I: Spatial Patterns of Concentrations in Biomass, Litter, and Soils, Environ. Sci. Technol., 3974-3981, doi:10.1021/es104384m, 2011.

Obrist, D., Johnson, D. W., and Edmonds, R. L.: Effects of vegetation type on mercury concentrations and pools in two adjacent coniferous and deciduous forests, J. Plant Nutr. Soil Sci., doi:10.1002/jpln.201000415, 2012.

Oechel, W. C., Vourlitis, G. L., Hastings, S. J., Zulueta, R. C., Hinzman, L., and Kane, D.: Acclimation of ecosystem $\mathrm{CO}_{2}$ exchange in the Alaskan Arctic in response to decadal climate warming, Nature, 406, 978-981, doi:10.1038/35023137, 2000.

Oleson, K. W., Niu, Z.-L., Yang, G.-Y., Lawrence, D. M., Thornton, P. E., Lawrence, P. J., Stockli, R., Dickinson, R. E., Bonan, G. B., Levis, S., Dai, A., and Qian, T.: Improvements to the Community Land Model and their impact on the hydrological cycle, J. Geophys. Res., G01021, doi:10.1029/2007JG000563, 2008.

Oren, R., Ellsworth, D. S., Johnsen, K. H., Phillips, N., Ewers, B. E., Maier, C., Schafer, K. V. R., McCarthy, H., Hendrey, G., McNulty, S. G., and Katul, G. G.: Soil fertility limits carbon sequestration by forest ecosystems in $\mathrm{CO}_{2}$-enriched atmosphere,
Nature, 411, 469-472, doi:10.1038/35078064, 2001.

Parton, W. J., Schimel, D. S., Cole, C. V., and Ojima, D. S.: Analysis of Factors Controlling Soil Organic Matter Levels in Great Plains Grasslands, Soil Sci. Soc. Am. J., 51, 1173-1179, doi:10.2136/sssaj1987.03615995005100050015x, 1987.

Pepper, D. A., Del Grosso, S. J., McMurtrie, R. E., and Parton, W. J.: Simulated carbon sink response of shortgrass steppe, tallgrass prairie and forest ecosystems to rising $\mathrm{CO}_{2}$, temperature and nitrogen input, Global Biogeochem. Cy., 19, 10.1029/2004gb002226, 2005.

Pokharel, A. K. and Obrist, D.: Fate of mercury in tree litter during decomposition, Biogeosciences, 8, 2507-2521, doi:10.5194/bg8-2507-2011, 2011.

Qian, T., Dai, A., Trenberth, K. E., and Oleson, K. W.: Simulation of global land surface conditions from 1948 to 2004: Part I: Forcing data and evaluations, J. Hydrometeorol., 953-975, doi:10.1175/JHM540.1, 2006.

Randerson, J. T., Thompson, M. V., Conway, T. J., Fung, I. Y., and Field, C. B.: The contribution of terrestrial sources and sinks to trends in the seasonal cycle of atmospheric carbon dioxide, Global Biogeochem. Cy., 535-560, doi:10.1029/97GB02268, 1997.

Randerson, J. T., Hoffman, F. M., Thornton, P. E., Mahowald, N. M., Lindsay, K., Lee, Y.-H., Nevison, C. D., Doney, S. C., Bonan, G., Stockli, R., Covey, C., Running, S. W., and Fung, I. Y.: Systematic assessment of terrestrial biogeochemistry in coupled climate - carbon models, Glob. Change Biol., doi:10.1111/j.13652486.2009.01912.x, 2009.

Rea, A. W., Keeler, G. J., and Scherbatskoy, T.: The deposition of mercury in throughfall and litterfall in the Lake Champlain watershed: A short-term study, Atmos. Environ., 30, 3257-3263, doi:10.1016/1352-2310(96)00087-8, 1996.

Reich, J. W. and Schlesinger, W. H.: The global carbon dioxide flux in soil respiration and its relationship to vegetation and climate, Tellus B, 44, 81-99, doi:10.1034/j.1600-0889.1992.t01-100001.x, 1992.

Rustad, L. R., Campbell, J., Marion, G., Norby, R., Mitchell, M., Hartley, A., Cornelissen, J., Gurevitch, J., and GcteNews: A meta-analysis of the response of soil respiration, net nitrogen mineralization, and aboveground plant growth to experimental ecosystem warming, Oecologia, 126, 543-562, doi:10.1007/s0044200005442001.

Saiz, G., Bird, M. I., Domingues, T., Schrodt, F., Schwarz, M., Feldpausch, T. R., Veenendaal, E., Djagbletey, G., Hien, F., Compaore, H., Diallo, A., and Lloyd, J.: Variation in soil carbon stocks and their determinants across a precipitation gradient in West Africa, Glob. Change Biol., v10.1111/j.13652486.2012.02657.x, 2012.

Schroeder, W. H. and Munthe, J.: Atmospheric mercury - An overview, Atmos. Environ., 32, 809-822, doi:10.1016/S13522310(97)00293-8, 1998.

Schuster, P. F., Krabbenhoft, D. P., Naftz, D. L., Cecil, L. D., Olson, M. L., Dewild, J. F., Susong, D. D., Green, J. R., and Abbott, M. L.: Atmospheric Mercury Deposition during the Last 270 Years:? A Glacial Ice Core Record of Natural and Anthropogenic Sources, Environ. Sci. Technol., 36, 2303-2310, doi:10.1021/es0157503, 2002.

Shen, W., Reynolds, J. F., and Hui, D.: Responses of dryland soil respiration and soil carbon pool size to abrupt vs. gradual and in- 
dividual vs. combined changes in soil temperature, precipitation, and atmospheric $\left[\mathrm{CO}_{2}\right]$ : a simulation analysis, Glob. Change Biol., 15, 2274-2294, doi:10.1111/j.1365-2486.2009.01857.x, 2009.

Sigler, J. M., Lee, X., and Munger, W.: Emission and LongRange Transport of Gaseous Mercury from a Large-Scale Canadian Boreal Forest Fire, Environ. Sci. Technol., 37, 4343-4347, doi:10.1021/es026401r, 2003.

Skyllberg, U., Xia, K., Bloom, P. R., Nater, E. A., and Bleam, W. F.: Binding of mercury(II) to reduced sulfur in soil organic matter along upland-peat soil transects, J. Environ. Qual., 29, 855-865, doi:10.2134/jeq2000.00472425002900030022x, 2000.

Smith-Downey, N. V., Sunderland, E. M., and Jacob, D. J.: Anthropogenic impacts on global storage and emissions of mercury from terrestrial soils: Insights from a new global model, J. Geophys. Res., 115, G03008, doi:10.1029/2009JG001124, 2010.

Stamenkovic, H., Gustin, M. S., Arnone, J. A., Johnson, D. W., Larsen, J. D., and Verburg, P. S. J.: Atmospheric mercury exchange with a tallgrass prairie ecosystem housed in mesocosms, Sci. Total Environ., 406, 227-238, doi:10.1016/j.scitotenv.2008.07.047, 2008.

Streets, D. G., Devane, M. K., Lu, Z., Bond, T. C., Sunderland, E. M., and Jacob, D. J.: All-Time Releases of Mercury to the Atmosphere from Human Activities, Environ. Sci. Technol., 45, 10485-10491, doi:10.1021/es202765m, 2011.

Talmon, Y., Sternberg, M., and Grunzweig, J. M.: Impact of rainfall manipulations and biotic controls on soil respiration in Mediterranean and desert ecosystems along an aridity gradient, Glob. Change Biol., 17, 1108-1118, doi:10.1111/j.13652486.2010.02285.x, 2011.

Tingey, D. T., Lee, E. H., Waschmann, R., Johnson, M. G., and Rygiewicz, P. T.: Does soil $\mathrm{CO}_{2}$ efflux acclimatize to elevated temperature and $\mathrm{CO}_{2}$ during long-term treatment of Douglasfir seedlings?, New Phytol., 170, 107-118, doi:10.1111/j.14698137.2006.01646.x, 2006.

Treseder, K. K., Egerton-Warburton, L. M., Allen, M. F., Cheng, Y., and Oechel, W. C.: Alteration of Soil Carbon Pools and Communities of Mycorrhizal Fungi in Chaparral Exposed to Elevated Carbon Dioxide, Ecosystems, 6, 786-796, doi:10.1007/s10021003-0182-4, 2003.
Turetsky, M. R., Harden, J. W., Friedli, H. R., Flannigan, M., Payne, N., Crock, J., and Radke, L.: Wildfires threaten mercury stocks in northern soils, Geophys. Res. Lett., 33, L16403, doi:10.1029/2005GL025595, 2006.

Ullrich, S. M., Tanton, T. W., and Abdrashitova, S. A.: Mercury in the Aquatic Environment: A Review of Factors Affecting Methylation, Crit. Rev. Environ Sci. Technol., 31, 241-293, doi:10.1080/20016491089226, 2001.

Wang, H., Ni, J., and Prentice, I.: Sensitivity of potential natural vegetation in China to projected changes in temperature, precipitation and atmospheric $\mathrm{CO}(2)$, Reg. Environ. Change, 11, 715727, doi:10.1007/s10113-011-0204-2, 2011.

Wang, S. P., Zhou, G. S., Gao, S. H., and Guo, J. P.: Soil organic carbon and labile carbon along a precipitation gradient and their responses to some environmental changes, Pedosphere, 15, 676680, 2005

Wigley, T.: The pre-industrial carbon dioxide level, Clim. Change, 5, 315-320, doi:10.1007/bf02423528, 1983.

Wu, Z., Dijkstra, P., Koch, G. W., PeÑUelas, J., and Hungate, B. A.: Responses of terrestrial ecosystems to temperature and precipitation change: a meta-analysis of experimental manipulation, Glob. Change Biol., 17, 927-942, doi:10.1111/j.13652486.2010.02302.x, 2011

Zhang, X., Zwiers, F. W., Hegerl, G. C., Lambert, F. G., Gillett, N P., Solomon, S., Stott, P. A., and Nozawa, T.: Detection of human influence on twentieth-century precipitation trends, Nature, 448, 461-465, doi:10.1038/nature06025, 2007.

Zheng, Z. M., Yu, G. R., Fu, Y. L., Wang, Y. S., Sun, X. M., and Wang, Y. H.: Temperature sensitivity of soil respiration is affected by prevailing climatic conditions and soil organic carbon content: A trans-China based case study, Soil Biol. Biochem., 41, 1531-1540, v10.1016/j.soilbio.2009.04.013, 2009.

Zhou, G., Wang, Y., and Wang, S.: Responses of grassland ecosystems to precipitation and land use along the Northeast China Transect, J. Veg. Sci., 13, 361-368, doi:10.1111/j.16541103.2002.tb02060.x, 2002.

Zhou, T. and Luo, Y.: Spatial patterns of ecosystem carbon residence time and NPP-driven carbon uptake in the conterminous United States, Global Biogeochem. Cy., 22, GB3032, doi:10.1029/2007GB002939, 2008.

Zhou, X., Talley, M., and Luo, Y.: Biomass, Litter, and Soil Respiration Along a Precipitation Gradient in Southern Great Plains, USA, Ecosystems, 12, 1369-1380, doi:10.1007/s10021009-9296-7, 2009. 